\title{
Imagens da destruição da cidade de Lakish pelo rei assírio Senaquerib: ensaio sobre os baixos-relevos pictóricos como agentes históricos
}

\author{
Images of the destruction of the city of Lachish \\ by the Assyrian king Sennacherib: essay on \\ pictorial bas-reliefs as historical agents
}

\section{Imágenes de la destrucción de la ciudad de Laquis por el rey asirio Senaquerib: ensayo sobre los bajorrelieves pictóricos como agentes históricos}

João Batista Ribeiro Santos*

Submetido em: 1-5-2021

Aceito em: 17-8-2021
* Universidade Metodista de São Paulo Pós-doutor em História Antiga E-mail: joao.ribeiro@metodista.br (iD)

As restrições da arte: ela em primeiro lugar, depois vêm as outras coisas, Emerson Pinzindin ${ }^{1}$

\begin{abstract}
RESUMO
O ensaio historiográfico tem o objetivo de analisar os baixos-relevos pictóricos expostos na Sala XXXVI do Palácio Sudoeste do rei Senaqueribe, na cidade de Nínive. Metodologicamente, apresentaremos crítica e contextualmente os relevos como agentes históricos considerando o público que lhes transfere sentido, e, portanto, em ambiente de encenações políticas do rei para as camadas privilegiadas da população. A exposição dos baixos-relevos oferece ao público a reconstrução dos eventos que fizeram parte do assédio e destruição da cidade de Lakish, uma potência militar localizada na Sefelah.

Palavras-chave: Lakish; Senaquerib; arte assíria; guerra no mundo antigo; antigo Israel.
\end{abstract}

\begin{abstract}
The historiographical essay aims to analyze the pictorial bas-reliefs exposed in Room XXXVI of the Southwest Palace of king Sennacherib, in the city of Nineveh. Methodologically, we will critically and contextually present the reliefs as historical agents considering the public that transfers meaning to them, and, therefore, in an environment of political performances by the king for the privileged sectors of the population. The bas-relief exhibition offers the public the reconstruction of the events that were part of the siege and destruction of the city of Lachish, a military potential located in Sephelah.

Keywords: Lachish; Sennacherib; Assyrian art; war in the ancient world; ancient Israel.

\section{RESUMEN}

El ensayo historiográfico tiene como objetivo analizar los bajorrelieves pictóricos expuestos en la Sala XXXVI del Palacio Suroeste del rey Senaquerib, en la ciudad de Nínive. Metodológicamente, presentaremos crítica y contextualmente los relieves como agentes históricos
\end{abstract}

Artista musical, declaração em "Buscando Bruskers: Pinzindin” (T1: E3, 2016 [Canal Arte 1]). 
considerando el público que les transfiere significado y, por tanto, en un ambiente de actuaciones políticas del rey para sectores privilegiados de la población. La exposición de los bajorrelieves ofrece al público la reconstrucción de los hechos que fueron parte del asedio y destrucción de la ciudad de Laquis, una potencial militar ubicada en Sefelá.

Palabras clave: Laquis; Senaquerib; arte asirio; guerra en el mundo antiguo; antiguo Israel.

\section{Introdução}

A materialidade artística da violência por meio da objetificação de políticas reais, muito mais do que a reconstrução de acontecimentos, não raro impossível tanto pela lonjura histórica quanto pela raridade de registros realizados por autoptes, tem subsidiado relevantes pesquisas acerca da expansão da Assíria (KUR a c. 911-745, início da construção de uma estrutura mundial: c. 774; período de domínio do mundo e queda: 744-612). De fato, tem-se considerado as diversas cenas que podem ser consideradas como representações da violência em seus diferentes suportes como proposição de "uma clara intenção de criar um monumento à violência" (NADALI, 2020, p. 632), com projeções dos poderes reais e golpes desferidos por membros da guarnição em missão, divindades e reis, de parte a parte segundo os ícones representativos. Com efeito, a acessibilidade dessas representações e do próprio acontecimento esse conjunto de eventos históricos - torna-se possível através dos relevos.

Portanto, ações violentas passam a fazer parte da paisagem por emergir da natureza do desenvolvimento do império, i.é, a expansão territorial, deportação cruzada, a acumulação de riquezas e a provincialização de pequenos reinos se fazem por meio de extermínios. A paisagem citadina passa a ser composta por monumentos, painéis, murais, templo do deus nacional ou da guerra, palácio do rei conquistador, assim como o espaço do conflito. A diferença consiste em que a violência é processada numa mutação objetiva: no êxito das campanhas, o rei assume, portanto, a liderança do aparato estatal de proteção aos cidadãos assírios, mas também o controle sobre a vida e a morte dos povos conquistados. Destarte, interessam-nos das linguagens artísticas o aspecto figurativo dos relevos como a violência mesma, como objeto da manifestação do ser e agente disseminado culturalmente.

A terceira campanha do rei Senaquerib ${ }^{2}$ (704-681; assírio: ${ }^{\mathrm{md}}$ EN.ZUŠEŠ.MEŠ-eri-ba; Sîn-aḥ̂̄e-erība) marcou seu projeto de expansão ao oeste do antigo Oriente-Próximo (fig. 1), começou pela região siro-eufratênia em direção à costa do Levante (fig. 2) avançando em duas etapas a partir das

2 Grafamos em português o nome do rei assírio Sîn-aḥ̂e-erība como "Senaquerib", sem a letra "e" final, seguindo a forma comum de grafia em francês (Sennacherib), inglês (Sennacherib) e espanhol (Senaquerib). 
terras fenícias e chegando às terras dos pelishtim. Nessa segunda etapa, a campanha chegou em Judah (assírio: KUR ia-ú-da-a-a), reino onde se localiza Tel Lakish (hebraico: Lakišs; atual Tell ed-Duweir) (fig. 3). Como enunciado por Norma Franklin (2018, p. 681), as condições sociais no sul do Levante eram de intensas disputas entre Assíria e Egito (Mi-iṣ-ri; assírio: KUR $m u-u s-r a-a-a)$, sendo os egípcios desde o ano de 724 um importante apoio político para a resistência de Judah aos pesados tributos pagos aos assírios.

De fato, Panhy (c. 751-716; hebraico: Sōo), faraó da XXV Dinastia Kushita que estende seus domínios para o sul do Levante, intervém antes atendendo a um pedido de socorro de Hoshea (732-724; hebraico: Hōsēa $)^{\text {) }}$, rei de Israel Norte (assírio: mât sir-'i-la-a-a). Oito anos depois, em meio a esse processo de provincialização assíria na região, chega ao poder em Judah o rei Hezekiah (716-687; assírio: $\left.{ }^{\mathrm{m}} h a-z a-q i-a-u ́\right)$.

Escribas do "Cilindro Rassam" sugerem a liderança de Hezekiah numa coalizão contra a Assíria logo depois da morte de Sargon II (721-705, Šarrukin), e anais deste rei assírio mencionam a presença de um oficial do faraó na cidade de Gaza (assírio: KUR ha-zi-ti) (FRANKLIN, 2018; LIVERANI, 2008, p. 185-89). O pacto de guerra contra o império neoassírio contava com o reino de Judah, Egito, cidades governadas por pelishtim na costa do Levante e possivelmente com o apoio da Babilônia. Senaquerib tem a intenção, portanto, de guerrear contra as forças egípcias inseridas nas atividades estatais do sul do Levante visando controlar a região (cf. USSISHKIN, 2014, p. 75). Nessa região, o faraó Shabaka (c. 716-702), sucessor de Panhyy, e seu corregente Shabataka (c. 702-690) revitalizaram o comércio do Egito com o Levante; após a morte de Sargon II, Shabataka aumentou o controle egípcio nos territórios. Isso gerou forte reação da Assíria, quadro político no qual a intensa disputa de poder influenciará diretamente na campanha de Senaquerib na costa desde a Fenícia, culminando com seus intensos ataques à cidade de Lakish no ano de 701 .

\section{Relevos como agentes históricos}

Lakish era uma cidade geograficamente estratégica na Shefelah - cerca de doze hectares, com ligação para a costa do Levante e situada em rota para o Egito e para a Jordânia -, restava estruturalmente a Lakish pouco da época do protetorado egípcio na costa do Levante na época amarniana (séculos XIV e XIII). ${ }^{3}$ A cidade foi reocupada no século X e teve reconstruídos os seus muros e fortalezas entre os séculos IX e VIII, mantinha numerosos guerrei-

3 A mesma Lakiša-Lakǐša mencionada na Idade do Bronze Tardio I-II nas cartas de Tell el-'Amarna (EA 287, 288, 328, 329, 335) e com sítio de assentamentos desde o Período Neolítico. Sobre os documentos de Tell el-Amarna, veja a importante obra em dois volumes de Mario Liverani (1998; 1999). 
ros com cocares em estilo turbante, cavaleiros, carros de guerra e cocheiros que a transformaram, na expressão de Franklin (2018, p. 682; cf. também LIVERANI, 2008, p. 178), em “um forte centro militar”. É essa Lakish que o rei Senaquerib e sua guarnição militar encontram; a situação geográfica e independência política da cidade a colocam como parte da periferia ameaçadora não segundo o plano de autodefesa assíria, mas como ameaça potencial ao plano de reconquistas do sul do Levante.

$\mathrm{Na}$ justificação do plano de reconquistas a geopolítica determinará "uma combinação de fatores recorrentes na história da expansão imperial, e das guerras em geral, deu início a um ciclo histórico: a 'mentalidade de cerco', a 'ação preventiva', a 'culpa do inimigo' e o 'imperialismo involuntário”" (LIVERANI, 2017, p. 116). A tradição mesopotâmia de tomar as populações das bordas como hostis, no caso de Lakish e Jerusalém, as duas cidades assediadas simultaneamente, deve ser abandonada sobretudo pela ausência de coalizão judaíta e, portanto, do fator "um contra muitos", proposto por Mario Liverani (2017, p. 120) como a mentalidade dos assédios. E então fica já definida a questão fundante acerca de quem é o agressor e quem é a vítima, deslocando para a estrutura ideológica as retóricas conceituais do império. ${ }^{4}$ Acrescentemos um motivo para a impossibilidade de "guerra justa", ele diz respeito à ausência de ordem de rendição de Senaquerib para Lakish como a enviada para a vizinha capital judaíta de Jerusalém. ${ }^{5}$

Essas aporias iniciais guiarão a busca dos contextos do assédio e destruição para além das ações violentas, estratégicas político-militares do império neoassírio que pertencem, nesse período de domínio mundial, à fase de provincialização e assirialização do Levante. ${ }^{6}$ Cabe, no entanto, como dado historiográfico uma postulação encontrada em Davide Nadali (2020, p. 641): desde o terceiro milênio a "violência foi exibida seguindo ações específicas

4 As retóricas são muitas, citemos três: "teoria do imperialismo defensivo", "guerra santa" e "guerra justa”. A concepção de um mundo multipolar, como existiu na Idade do Bronze Médio através dos grandes reinos e reinos com controle estrutural de cidades do seu entorno no norte do Levante e na Idade do Bronze Tardio no norte e na costa do Levante, é improvável na Idade do Ferro II-III.

5 Veja 2Reis 18. Em todas as citações da Bíblia hebraica a referência será sempre a BHS (ELLIGER; RUDOLPH, 1997).

6 A terceira campanha de Senaquerib, em síntese de pesquisa realizada por Norma Franklin: "No total, esses eventos se estenderam por uma área de $400 \mathrm{~km}$ de norte a sul, lidaram com 70 entidades políticas e resultaram na deportação de dezenas de milhares de pessoas. Pelo menos 13 cidades muradas tiveram seus reis rebeldes substituídos, as cidades de Eltekeh e Timnah foram saqueadas, os nobres de Ekron foram punidos, até 46 cidades da Judeia foram destruídas e possivelmente até um milhão de pessoas foram afetadas. No entanto, Jerusalém e Hezekiah sobreviveram, comparativamente intocados devido ao aliado esquecido de Judah, a 25 Dinastia Kushita, que governou o Alto e o Baixo Egito" (2018, p. 680 - trad. nossa). 
e agendas políticas" na Síria e Mesopotâmia. Então, a violência extrapola os limites geográficos e circunstancialidades de lugar porque é inserida num processo cultural cujo impacto requererá reações dos seus observadores.

O conjunto artefatual encontrado na Sala XXXVI (figs. 4 a 6) do "Palácio Sudoeste", na capital de Nínive (atual Mosul; assírio: NINA.KI), se destaca nas pesquisas pela enorme dimensão socioliterária da Bíblia hebraica, mas o palácio conservou cerca de treze relevos atribuídos a Senaquerib e dois, atribuídos a Aššurbanipal (668-631, Aššr-bāni-apli), último rei da dinastia iniciada por Tiglat-pileser III (744-727, Tukulti-apil-Ešarra) (figs. 7 a 26). Os detalhes que demonstram as ações assírias por meio das mensagens políticas imagéticas - assédio, sangue, empalamento, afogamento, esfolamento, decapitação da cabeça e outros membros do corpo, deportação, destruição, coações etc. -, como parte da missão imperial que se ajusta a uma espécie de glorificação da violência, reconhecem alguns aspectos identitários ${ }^{7}$ apenas como testemunho à maneira de autenticidade do que se expõe.

A tradição de decorar salas do palácio, fortemente acentuada nesse período em que ficam caracterizados objetivamente os modos de vida real assírios, pode ser tomada como responsável pela exposição das cenas de guerra ocorridas em Lakish. À época da campanha de Senaquerib, no ano de 701, a cidade estava incorporada ao reino levantino de Judah, no reinado de Hezekiah.

No conjunto de relevos, o assédio e invasão da cidade são interpretados a partir de um sistema de referências de eventos. Compreendendo o artefato como o fazem Davide Nadali e Ludovico Portuese (2020, p. 129), como uma obra de arte:

a imagem é feita, ou seja, é concebida; a imagem reproduz, em diferentes meios, a imagem por meio de processos de criação (o artista forma física e concretamente o objeto) e de correspondência (o artista corrige, modifica, reajusta o protótipo original).

Assim o relevo se torna um agente histórico que em suas funções apresenta com outros agentes, reproduzidos em imagens ou ocultados, um ou vários campos de atuação social.

Para alcançarmos a historicidade dos relevos serão distinguidos seus diversos âmbitos de atuação à maneira de objetividade dos agentes, visando os contextos de suas significações. Os anais de Senaquerib apresentam em

\footnotetext{
Sobre as questões étnico-raciais persiste o debate sobre, por exemplo, o decepamento de cabeças por membros da guarnição assíria e em torno dos contrastes visuais, mas também por procedimentos de líderes babilônios (COLLINS, 2014, principalmente p. 632-33).
} 
escalas a narrativa do vencedor e o rei da cidade destruída, um homem sem qualidades, numa estrutura literária dos "conflitos mitológicos" (BATTINI, 2019, p. 339), enquanto na Bíblia hebraica o historiógrafo reelabora "experiências do período posterior a 597 a.C.", 8 i.é, uma narrativa que em grande parte se refere ao tempo da ocupação do império neobabilônio na forma como descreve o pagamento de tributo e até quando retroprojeta o reinado do faraó Taraca, da Dinastia Kushita, que só começou a reinar no ano de 690 (SCHMID, 2013, p. 150-51). Segundo Laura Battini (2019, p. 339), em nenhuma das duas narrativas temos "uma descrição histórica objetiva dos eventos, mas nada é pura invenção”.

Além disso, nem as inscrições nem os relevos assírios mencionam o assédio da cidade, as inscrições nas duas pequenas placas nada mencionam e os relevos da Sala XXXVI não conduzem necessariamente à destruição da cidade pela guarnição assíria. Não o afirmam as imagens, temos as cenas da captação do butim:

Portanto, nada pode provar sem dúvida que o cerco representado é realmente o de Lakish. O que é tão atraente nas imagens é sua ambiguidade. O cerco da sala XXXVI do Palácio Sudoeste de Nínive pode ser o de qualquer cidade do Levante, talvez tenha sido considerado o de Jerusalém. Qual era o conhecimento geográfico das pessoas que entravam no palácio? Elas poderiam distinguir entre Lakish e Jerusalém?

Outro ponto importante diz respeito à legibilidade das legendas. Não é apenas o problema de saber quem era capaz de ler cuneiforme em um mundo de língua aramaica, mas também a presença ou ausência de condições que permitem às pessoas ler as legendas. Em outras palavras, as legendas estão em uma altura fácil e normal e expostas à luz suficiente ou não? A luz é um ponto importante, não só na arquitetura mas também nos relevos, embora muitas vezes seja negligenciada. Se não houver luz suficiente, ninguém entrando na sala poderá ler a legenda. Na sala XXXVI, as legendas estão a $1,60 \mathrm{~m}$ de altura, perfeitas para serem vistas. Para a luz não há resposta fácil, depende da reconstrução arquitetônica e permanece conjuntural: as paredes não são conservadas em altura suficiente para permitir uma experiência direta das janelas. (BATTINI, 2019, p. $340-42$ - trad. nossa).

\footnotetext{
Cf. 2Reis 18-20, especialmente 18.14-16, onde o pagamento do tributo é mencionado antes da ocorrência do assédio da guarnição assíria, em 18.17-19; a menção ao faraó Taraca consta em 19.9 e o indício literário do "assassinato de Senaquerib e a sucessão de seu filho Assarhadon ao trono assírio imediatamente após 701", consta em 19.36-37 - esse evento ocorreu, na verdade, em 681/680. Em uma possível interpretação teológico-sacerdotal, talvez a morte de Senaquerib sugira a aguardada morte do rei do império neobabilônio Nabonido (555-539). Especificamente sobre o assédio e destruição da cidade de Lakish, os historiógrafos deuteronomísticos nada sabem, quiçá conheçam a rota pela qual a guarnição assíria deverá chegar a Jerusalém, conforme 2Reis 18.14, 17 (cf. SCHMID, 2013, p. 150-51; DEVER, 2010, p. 529-30; MIEROOP, 2020, p. 355-68).
} 
Battini desafia a nossa atenção com suas hipóteses em relação à exposição, mais ainda quando afirma que os relevos da Sala XXXVI nada têm de original quanto ao estilo da arte mural assíria, eles são "uma versão padronizada do ataque assírio a uma cidade" (BATTINI, 2019, p. 344). ${ }^{9}$ Outra evidência histórica em relação aos relevos como agentes diz respeito à linguagem empregada; o suporte recebeu do artista apenas duas placas com pequenas inscrições informativas, demonstrando assim o predomínio artístico das imagens. Sem elas, talvez ficaríamos sabendo do fato por meio de atestações fragmentárias ex eventu, apesar da existência de outros monumentos de Senaquerib em relevos, prismas e cilindros. Com os relevos, temos outra forma de artefato - outro produto social -, portanto, ao invés da descrição textual, a materialização do acontecimento é objetificada imageticamente.

Essa materialização do acontecimento à maneira de reconstrução permite duas abordagens acerca do contexto, sendo que suas mentalidades coletivas no quadro histórico da entidade política dirigem a produção iconográfica. $\mathrm{Na}$ compreensão de Nadali e Portuese (2020), eis as duas abordagens: $:^{10} \mathrm{O}$ artefato em sua locação projeta as "estruturas sociais, circunstâncias políticas, premissas religiosas e culturais", afetando fortemente a capacidade das pessoas em se emocionar e a intericonicidade linguística - "a evidência da existência de um atlas mnemônico de referências implícito e explícito" pela qual os agentes produtores do conjunto artefatual - relevos, inscrições, locação, iluminação, meio de acesso - revelam a quem a comunicação/exposição real se dirige preferencialmente. Esse dinamismo vital do agente histórico foi projetado para a Sala XXXVI.

O dinamismo faz parte da grande estrutura imperial assíria; ${ }^{11}$ no âmbito cultural, mantém-se o interesse por temas decorativos, grandes painéis artefatuais e inscrições. A mudança estrutural em escala palacial ganha maior significância com o retorno da capital para Nínive. Na avaliação de Nadali (2019, p. 330), essa mudança estética, ocorrida em consequência das transformações empreendidas pelo novo rei, projeta imagética e socialmente os "membros da corte, aristocratas e altos dignitários" para diferentes funções nas estruturas imperiais. Com isso, Nadali propõe analisar os relevos considerando o fato de eles fazerem parte do "processo de formação do império". Paul Collins (2014, p. 620) distinguiu as obras entendendo que "os artistas criaram mundos muito críveis; o conflito não é mascarado por tratá-lo

\footnotetext{
Para análise diferente, cf. USSISHKIN, 2014, p. 98-9.

Veja p. 134-46, especialmente p. 134, 141, 143, 145-46.

11 O reinado de Senaquerib assume-se como herdeiro das transformações iniciadas pelo rei Tiglat-pileser III e mantidas por Sargon II, seu antecessor.
} 
como definido em tempo e paz míticos, mas os eventos históricos reais são descritos, embora como versões fortemente selecionadas". Talvez devamos tomá-los como apresentações reveladoras - por identidades: época, dinastia, religião - da organização e prática de um poder no qual o rei está fazendo a vontade do deus Aššur ( $\left.{ }^{\mathrm{d}} a s^{2}-{ }^{\prime} u r\right) .{ }^{12}$

Parte da organização, a obra de arte afixa como memória cultural a prática do poder e as cenas sem a moldura do lugar, que expõem os modos de existência das obras de arte, retêm a realidade da concepção do rei e da recepção dos artistas. Os diferentes olhares públicos não têm poder para reinterpretar politicamente a natureza do relevo, i.é, avaliar a perspectiva palacial. Os relevos com cenas repletas de símbolos que designam a condição superior da Assíria, não mera propaganda ideológica, visto que, na reconstrução dos eventos no quadro das funções da realeza, reservam algumas metáforas para serem interpretadas pela população.

O método que se depreende a partir do que foi postulado é que, assentindo com Collins (2014, p. 636), "os relevos e pinturas das paredes faziam, portanto, parte das propriedades socialmente afetivas do palácio, seu arsenal psicológico". Nada obstante, ao explanar e expressar o progresso à guisa de realização e herança reais (NADALI, 2019, p. 332), a obra de arte participa do programa de construção do império no sistema de referências históricas. $\mathrm{Na}$ Idade do Ferro IIB-C, entre os séculos VIII e VII, a extensão do império neoassírio cobre geograficamente do Golfo Pérsico ao Mediterrâneo oriental; daí, os acessos aos territórios judaítas e de controle filisteu de Azor, Ekron (assírio: URU am-qar-ru-na), Ashkelon, Gaza, Ashdod e Lakish.

Os relevos demonstram que os assírios eram instrumentalmente treinados para colocar em prática uma de duas estratégias, a depender do meio ambiente em que ocorreria o conflito - uma para guerra campal e outra, praticada visando a captura de cidade. Esse último caso seria evitável pelos assírios porque o assédio, as escalas de invasão e as batalhas armadas consumiam maior quantidade de recursos humanos e materiais. ${ }^{13}$ Visualizando a comunicação oficial, a translação das culturas assírias para os demais povos

12 Veja, por ex., a cerimônia cúltica na fig. 26.

13 De forma circunstancialmente diferente, a Assíria também intervinha em conflitos envolvendo entidades políticas localizadas em região de avanço das suas guarnições: afixação de limites físicos em cidade, ausência de um grande rei ou presença imperial em desacordos fronteiriços, represálias, rivalidade entre grupos étnicos por predomínio local, reação às políticas de expansão territorial ou herança de cultura ancestral. Por exemplo: Adad-nērārī III (810-783) intermediou a solução de conflito para a afixação de limites na cidade de Nahlasi nas margens do rio Orontes, disputada entre as cidades de Hुamat, governada por Zakkur, e Arpad/Bīt-Agūsi (Hูa-la-ab/Aleppo), governada por Attār-šumkī I (805-796) - há, porém, dúvida quanto à identidade do rei alepino em relação à designação dinástica Attār-šumkī I ou Attār-šumkī II (assírio: ' ${ }^{m} a$-tar-šúm-qa) (YOUNGER, 2016, p. 524, 536). 
é mediada pelo presentismo da atividade do rei. É nesse sentido que a obra de arte produz a presença do império e a figura do rei, aquele que está na origem do acontecimento e justifica a sincronia ideológica.

Mesmo com tal projeto real que visa demonstrar a superioridade das guarnições assírias, como sublinhado por Nadali (2019, p. 336), com "representações hiperbólicas da realidade", os relevos são fontes confiáveis, conquanto se considere a mentalidade interpretativa e a capacidade de criação artística dos escultores. Em ambos, predominam a política e o sistema cultural assírios, com as próprias obras de arte como seus agentes de natureza performativa, cenograficamente participante daquele mundo. Nesse caso, a condição para a produção é determinada pelo contexto político, mas este limite rompe-se quando o relevo transmite os episódios com o intuito de informar sobre os feitos do rei para expandir o império e mesmo as bordas por ele arbitradas. Mas, segundo Luc Bachelot (1991, p. 113), a realidade perceptiva muda a depender da atribuição à peça e da precisão do episódio apresentado. Isso depende das dimensões empregadas tendo em vista o espaço que se quer controlado, levando-se em conta a possibilidade de um maior número de detalhes ou maior desenvolvimento de representações numa única obra.

Parece-nos aplicável aqui a terceira característica das fontes neoassírias destacada por Bachelot (1991), a atividade simbólica, muito mais do que a primeira ("o exercício de um poder absoluto") e a segunda ("a violência que se manifesta pelas guerras”). A linguagem simbólica discursiva volta-se como uma questão central, em relação à prática do poder do rei e à violência, por produzir a presença de conjunto de fatos impossível de ser reconstruído; logo, nos usos dos fatos, a linguagem objetificada torna-se a agente social pela qual o poder e a violência justificam fortemente a realidade antes apenas prevista ou por vezes antevista. O diálogo do rei com os seus súditos passa a ser intenso e cotidiano porque os mediadores - os relevos - cumprem função explanatória ao público.

Com relação à presença imperial no sul do Levante, os cercos e posteriores conflitos tinham por finalidade transformar os pequenos reinos e cidades-Estado com alguma relevância econômica e tecnológica em Estados provinciais. Por isso o controle das estruturas das cidades fazia parte do plano de expansão, principalmente no século IX; as tentativas de apropriação de territórios ricos em recursos naturais estão entre as razões dos conflitos (ABRAHAMI, 2014, p. 220-21). No oeste do vale do Eufrates, dentre os motivos estão as rotas de comércio marítimo, as fontes de água dos vales e a produção agricultural irrigada. 
O rei Senaquerib, cujo reinado faz parte do período de predomínio assírio no Levante (c. 745-632), reina num período em que a Assíria se encontra na plenitude do seu poder, logo depois de conquistar a Baixa Mesopotâmia, territórios da Babilônia (Bäb-ilī; assírio: KUR kár-dun-ia-áśs) e cidades eufratênias (Ur, Eridu, Uruk, Nippur, Borsippa, Sippar). No sul do Levante, desce para o extremo sul das terras de Judah e da pentápole governada por pelishtim, onde se localiza Lakish. Durante o seu reinado as relações com o Levante foram intensificadas conforme cresciam as manifestações contrárias aos interesses imperiais na região, demonstradas pelo rei fenício da cidade-Estado de Sidon (assírio: URU și-du-un-na-a-a), Lule, pelo rei Șidqāa da antes leal cidade de Ashkelon, e pelo rei Hezekiah de Judah, além da população da cidade de Ekron, ${ }^{14}$ encorajados pela emergência de poderes babilônios, da terra de Tiro (Şūr; assírio: KUR șur-ri) e do Egito.

No entanto, diante da reação assíria, Lule fugiu para o Chipre, Sidka foi exilado para a Assíria e a cidade de Jerusalém (assírio: URU ur-as-li-im-ma), a capital judaíta, foi sitiada. ${ }^{15}$ Geograficamente, a resistência política mobilizou as populações levantinas; ao leste na rota transjordaniana, os reis Pedael de Ammon, Kamošnadab de Moab e Ayyaram de Edom submeteram-se ao pagamento de tributo. Nesses contextos, Lakish foi uma das cidades a oferecer resistência. $\mathrm{O}$ acontecimento foi tão significativo que o cerco e tributação a Jerusalém não mereceu nenhum testemunho iconográfico palacial.

Os diferentes ambientes possibilitavam avaliar as várias dimensões estratégicas para a guerra. Em relação a isso, os relevos do cerco de Lakish são interpretados por Philippe Abrahami no sentido de representação da tática de guerra:

$\mathrm{O}$ ataque no centro, realizado conjuntamente com uma manobra de envolvimento nas laterais, ou ainda o impulso maciço no meio do dispositivo inimigo, a aposta é conseguir que o meio do dispositivo desmorone o mais rápido possível (em capturar o rei inimigo, por exemplo, ou forçá-lo a fugir). (ABRAHAMI, 2014, p. 223 - trad. nossa).

Mas o conjunto de relevos também demonstra que a fortificação da cidade judaíta fora construída para resistir a fortes tentativas de invasão; no iminente desbloqueio, os defensores reforçaram as muralhas com muros de arrimo ou terraplenagem nas rampas de ataques dos aríetes assírios.

Perspectivamente, em meio à guerra, os moradores da cidade preparavam novas construções que lhes possibilitassem sobreviver aos ataques (cf. armas e componentes nas figs. 27 e 28) e, com isso, dificultando o acesso

14 Posteriormente, o rei Senaquerib instalou Padī como rei pró-assírio.

15 Sobre as ações de Senaquerib contra seus opositores na região, cf. SCHNEIDER, 2014, p. 102-03. 
da guarnição assíria. De acordo com Tammi J. Schneider (2014, p. 103), “as escavações no local confirmam muitos elementos, incluindo a rampa de cerco, a parede contradefensiva e a devastação". Com efeito, as cenas de forte dramaticidade do relevo reproduzindo o conflito dimensionam as dificuldades que os assírios tiveram que superar. Dificuldades geográfica, baseado na estrutura do sistema de proteção local - a cidade foi edificada no cume de uma montanha e contava em seu entorno com muralhas duplicadas, o seu sistema de portões garantia-lhe a restrição do acesso -, e humana, pelas forças de defesa. Além dos relevos, a quantidade de mortos na vala transformada em cemitério indica um índice de milhares de combatentes.

O que se encontrou no sítio arqueológico, ou seja, dentro da cidade, atesta a historiografia visual dos artistas:

Aqui é revelada uma rampa de cerco ao longo da encosta sudoeste, uma contrarrampa dentro da cidade e um incêndio massivo em toda a cidade acompanhado por muitas pontas de flecha, pedras de estilingue, fragmentos de armadura de escama e uma vala comum (mais de 1.500 indivíduos) abaixo do local. (HARDIN, 2014, p. 749-50 - trad. nossa).

A cada episódio a informação visual mostra a evolução militar como a explanar individuações da guerra como parte do todo espacializado, a campanha da guarnição. Esta técnica é uma particularidade dos relevos de Senaquerib. No relevo da guerra de Lakish os detalhes iconográficos suprem a ausência literária, sumarizada na legenda "Senaquerib, rei da Assíria, sentado em seu trono enquanto o butim de Lakish passa diante dele" (BACHELOT, 1991, p. 114). À maneira de legenda museológica, consta o que o artista entende que o público precisa saber para seguir apreciando, não o que lhe ajude a compreender o sentido do "turbilhão" de personagens e elementos diversos dos relevos para interpretar o acontecimento.

Nesse turbilhão, uma função especial coube ao rei em consequência do domínio do perspectivismo da aparência, mediante a produção da presença imperial em que ele transmite a sua mensagem, emite a natureza da verdade do império. ${ }^{16}$ A questão de plano de fundo seria então apreender cada imagem precavendo-se de tomá-la como objetivamente propagandística. No Levante, mesmo em anais ou inscrições monumentais aramitas, o que se poderia propor como conteúdo panfletário da mensagem pode ser alguma

16 Em enunciação de Katia Maria Paim Pozzer (2013, p. 29, 30), “os relevos assírios evidenciam certa verdade histórica, ainda que sejam banhados em um discurso ideológico e propagandístico”, especialmente porque as "imagens não são uma cópia do real”. Nesse mesmo sentido, a ficção se torna uma representação evidentemente política em fontes literárias reais, como destacávamos em relação à Antiguidade (SANTOS, 2013, p. 8): "Nem sempre é possível distinguir quando a narração da história registra realidade ou imaginação, pelo fato de não existir distinção clara e permanente do que é historiografia ou biografia". 
legitimação do âmbito do assim chamado direito divino, introduzindo a atividade guerreira do rei. ${ }^{17}$

Desta forma, à mensagem política pertencem as memórias teologicamente interpretativas da história: a reprodução iconográfica da guerra não excluiu a divinação profética e a presença de ícones divinos ${ }^{18}$, como vemos na designação de pertença fundadora indicada na cerimônia presidida ou mediada por dois sacerdotes, onde aparecem nos carros de guerra estandartes de divindades. Em adição, os agentes das linguagens sempre foram os relevos e neles estão as respostas acerca da importância da terceira campanha do rei. No sentido dos efeitos psicológicos da formação consciente das emoções por meio da visualização dos artefatos artísticos, Battini (2019, p. 338; cf. também NADALI; PORTUESE, 2020) entende que "no caso dos relevos, talvez seja também uma reescrita de eventos históricos e, portanto, uma memória consentida".

Não o fato de o assédio estar em apenas um dos quinze murais escultóricos mas pelos artistas terem prescindido de sinais gráficos, os eventos deixaram o domínio perspectivo do rei bem claro. Talvez Battini tenha chegado ao ponto a que distinguimos baseada nas noções de informação:

Do ponto de vista assírio, não há foco epigráfico sobre o cerco de Lakish nos anais de Senaquerib, nem reivindicação clara do cerco de Jerusalém, não há caracterização iconográfica específica da cidade atacada, nem a escolha de um local especial e sala amplamente frequentada. Em suma, da terceira campanha de Senaquerib temos mais silêncios do que palavras. (BATTINI, 2019, p. 353 - trad. nossa).

Destarte, a ênfase nunca esteve em Jerusalém, ainda que a importância de Lakish seja relativizada pela epigrafia historiográfica da Bíblia hebraica. Nesse sentido, mesmo considerando a sua memória do período neobabilônio, o registro hebraico indiciário do insucesso de Senaquerib na capital judaíta e de seu assassinato por rebeldes da corte ninivita ganha valor de fonte histórica. ${ }^{19}$

Em Lakish também foi encontrado um fragmento de uma placa, designado como "inscrição de Azekah", inicialmente atribuído tanto a Tiglat- pileser III quanto a Sargon II, mas atualmente tem sido incorporado às fontes da campanha de Senaquerib no sul do Levante em 701. Essa fonte

17 Justifica-se ao visitante ou leitor a apropriação de território no quadro do poder político e das guerras de Aššur.

18 Talvez devamos realmente incluir o narcisismo da realeza no trono!

19 Cf. nota 6. Em adição, William G. Dever (2010, p. 529) afirma que as análises comparativas das narrações em 2Reis (Bíblia hebraica) e em fontes neoassírias e neobabilônias demonstram que "os autores e editores de Reis recorreram a fontes amplas e, em alguns casos, eles até possuíam relatos de testemunhas oculares". 
contém vinte e uma linhas e faz referência a Judah, na linha 3: "[ Aššur, meu senhor, me apoi] ou e para a terra de Ju[dah eu marchei. No] decorrer da minha campanha, a homenagem dos re[is de ... eu recebi]"; menciona o rei Hezekiah de Judah na linha 4: "[ pelo pod]er de Aššur, meu senhor, o distrito [de Hezek]iah de Judah, como [ ]" e na linha 11: "[ a cidade ] uma realeza dos pelishtim, que Ez[ek]iah havia tomado e fortificado para si [ ]" (COS, cf. COGAN, 2000, p. 304-5 - trad. nossa).

Sempre restará na imagem uma "indeterminação interpretativa" (BACHELOT, 1991, p. 121-22), por isso mesmo temos que divergir do postulado enunciado por Bachelot (1991, p. 115) quando idealiza o império como uma estrutura que busca elaborar uma mensagem compreensível à população por entender a sua heterogeneidade. A nosso ver, os valores destinados ao público podem ser vistos paralelamente à evolução da arte - em nada há explanação ao senso comum -, seguindo a evolução das estratégias e instrumentos de guerra que precedem os meios utilizados para a integração entre regiões.

Em adição, a moral de guerra praticada entre os grandes reinos, em última instância, não tem validade para a cidade-Estado de Lakish. Os relevos da deportação e da execução de moradores e guerreiros de Lakish contrastam com os processos assírios referentes à guerra em Eltekeh; os guerreiros capturados nessa cidade do noroeste de Judah foram reassentados por Senaquerib, certamente considerando a identidade étnico-racial dos egípcios e a pertença social quase milenar dos pelishtim a eles (FRANKLIN, 2018, p. 683-84). Talvez estejamos diante de um caso de exceção às deportações cruzadas, como procedeu Shalmanasar V (726-722), por exemplo, em relação a Israel Norte e sua capital, Samaria.

\section{A comunicação real, a locação e a assistência}

Retomando a questão da afecção, consideraremos o público a que se destina e que se deixa apreciar psicológica e politicamente o programa de monumentalização da Assíria. Para o alcance, consideremos a função das salas, a escala e o grau de visibilidade do relevo. ${ }^{20} \mathrm{O}$ principal objetivo das inscrições, relevos e demais monumentos não é a propaganda, embora não devamos ignorar as linguagens que guiam o público na cenografia de conquistas ao mesmo tempo em que fundamentam uma ideologia; ${ }^{21}$ os significados, i.é, as imagens mentais, transmitidos retornam na forma de diferentes reações da audiência por seus valores espelhados.

\footnotetext{
20 Recomendamos a importante pesquisa de Ariel Bagg (2016) sobre o público das inscrições e obras de arte reais assírias.

21 Para um testemunho material no Levante, veja SANTOS, 2019.
} 
Portanto, afora a população da cidade em que um monumento é exibido ou em que a inscrição é lida ao ar livre, ou carregada em procissão como o rei e a divindade dinástica, esse público com acesso às salas privadas do palácio (existiam áreas públicas no complexo do palácio) caracteriza-se por fazer parte das elites governantes. (Presumivelmente por parte: oficiais militares; grandes proprietários; diplomatas; eruditos; administradores e sacerdotes reais; por fim, letrados com capacidade de entender uma imagem, ler um documento em cuneiforme babilônio e decifrar sistemas de escritas.)

Na concepção de mundo da autorrepresentação palacial de Senaquerib, as "paixões consumidoras", para usar uma expressão de Allison Karmel Thomason (2004, p. 152), que causavam prazer estavam também na mesa, ou melhor, procediam da cozinha. Um relevo ${ }^{22}$ do Palácio Sudoeste de Nínive comprova a associação de prazeres da guerra de conquista e dos banquetes: uma espécie de procissão de servidores carregando grandes travessas com diversos tipos de alimentos para um banquete celebrativo (THOMASON, 2004, p. 154). As realidades visuais transmitem, na forma de mensagem real, a retórica política pela qual se deve conhecer os poderes ou habilidades e preferências ou atividades pessoais do rei. É interessante o ponto de vista de David Ussishkin sobre a curadoria da exposição:

Na minha visão, o ponto de vantagem particular a partir do qual Lakish é mostrado no relevo tem por referência o sudoeste do monte, bem em frente ao local presumido do acampamento assírio, entre ele e a cidade, e de frente para o principal ponto de ataque. Acredito que este seja o local exato onde Senaquerib, o comandante supremo, sentou-se em seu belo trono, conduziu a batalha e depois revisou os carregadores do butim e os deportados. Consequentemente, acredito que os relevos de Lakish apresentam a cidade sitiada vista pelos olhos do próprio Senaquerib em seu posto de comando. (2014, p. 89 - trad. nossa).

Esse dinamismo performático do mundo material, portanto encenado por uma variedade de agentes históricos, é o responsável pela construção da identidade pública real. E há muitos motivos para isso. A comunicação artefatual da identidade pública real apresenta em si, como documentos monumentais - estátuas, estatuetas, placas com inscrições, estelas e pequenos relevos rituais decorativos, painéis, prismas, cilindros e alguns utensílios cúlticos -, o poder militar, a capacidade de realização e a conexão divina. A variedade iconográfica impossibilita uma maior clareza acerca da audiência original, portanto requer-se examinar o acesso aos lugares de exposição para estabelecer possíveis relações. Luis R. Siddall (2018, p. 59-60) nos informa

22 British Museum N. 124799 (Reg. N. 1851,0902.10). 
que as estelas de inscrições e anais reais de Senaquerib foram expostas em paredes dos palácios e templos; o fato de esses lugares não serem as únicas locações, além da natureza ideológica e a referência imagética, os contextos pelos quais são comunicadas as obras de arte refletem o público. Mas seria razoável destacar as pessoas com acesso a salas do palácio e do templo como leitores dos anais e apreciadores dos relevos.

Um monumento artístico erigido em estrada de acesso à capital do império e a cidades provinciais, de acordo com Siddall (2018, p. 61), "pode-se imaginar que qualquer pessoa viajando na estrada, de soldados assírios e administradores a mercadores particulares, teria visto"; no caso de inscrições, o viajante que "fosse alfabetizado poderia muito bem ter tido tempo para ler as estelas". O local de exposição indica a audiência que se tem em vista, inclusive dos moradores das proximidades, vice versa, a natureza da inscrição e do monumento.

As variadas apresentações determinam as locações e deixam claro cada público-alvo: externamente, são os moradores das cidades que passam a ser incorporadas ao império e os usuários das suas vias de ligação, numa interação informativa transregional; internamente, a paisagem da capital compartilha das mesmas ações violentas, mas o rei se dirige aos assírios em termos de cordialidade assegurando-lhes o programa de construções reais. Para Siddall (2018, p. 61), "a brutalidade da comunicação aos moradores locais é contrabalançada por um tema abrangente do rei como provedor de seu povo". Além disso, o olhar externo está presente na capital por meio do estrangeiro cuja assimilação no contexto das funções da sociedade ocorre por um processo etnológico de longa duração.

Há que ser considerado, por exemplo, como grupos de interesses políticos sobreviventes em cidades controladas pela Assíria estabeleciam relações em face ao cruzamento com novas identidades étnicas e sociais, mas também em face às novas linguagens. A complexidade em estabelecer uma significação sobre o "estrangeiro" tem permitido a variabilidade de atribuições, o motivo se deve ao fato de os modelos tomados para a etnicidade serem fluidos (STREIT, 2019, p. 356) e os indícios culturais, nem sempre considerados.

Para considerarmos uma não-audiência por princípios políticos. Os arquivos históricos dos períodos arqueológicos do Bronze Tardio e do Ferro I que registram eventos que dizem respeito a Lakish ${ }^{23}$ podem nos informar acerca dos assentamentos e povoamento, circunstancialmente pode indicar caracte-

23 Katharina Streit (2019, p. 359) menciona a correspondência de Tell el-Amarna, o Papiro Hermitage 1116A, citações em camadas literárias da Bíblia hebraica, especialmente 2Reis 18.13-14, e relevos do palácio de Nínive. 
rísticas herdadas pelos moradores da cidade no século VIII. Nesse sentido, as relações que nem sempre caracterizavam subalternidade para com o Egito no século XIV, apesar de participar da rede comercial levantina controlada pelos egípcios, demonstram através da sua linguagem diplomática um projeto político particular de cidade-Estado.

Em um contexto da formação da sociedade, os três templos escavados - sendo que um situa-se na acrópole da cidade (ugarítico: Șapānu; hebraico: Șāponn) -, os objetos importados com nomes de reis egípcios, a produção local de cerâmica, os prédios em estilo egípcio, o sistema local de taxação e a divisão do serviço dos templos em categorias sociais demonstram que a cidade de Lakish tinha características culturais e relações diplomáticas com alguma semelhança com a cidade-Estado de Ugarit.

Em síntese: a identidade cultural egípcia deve ser localizada na origem da resistência política da cidade aos povos aramitas do norte do Levante e, principalmente, ao trato de vassalagem imposto pela Assíria. Isso nos leva não apenas à impressão dos relevos mas também ao impacto das palavras enunciadas em duas placas (fig. 23) da Sala XXXVI:

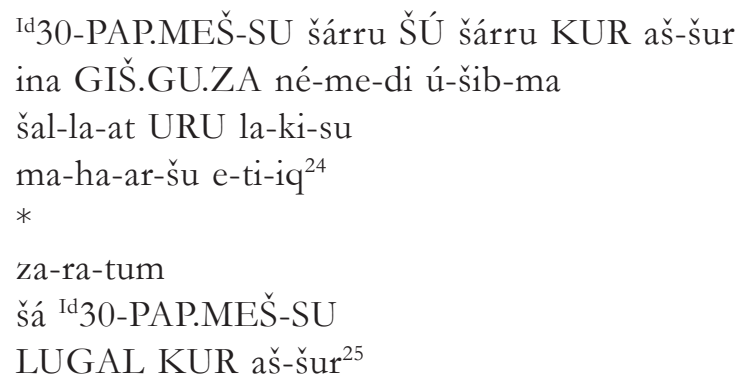

24 Transliteração da inscrição cuneiforme que se encontra diante do rei Senaquerib em seu trono (POZZER, 2013, p. 27).

25 Transliteração da inscrição cuneiforme que se encontra acima da tenda real no acampamento militar (POZZER, 2013, p. 28).

26 Cf. BATTINI, 2019, p. 342 - trad. e disposição espacial da inscrição nossas; veja também: BACHELOT, 1991, p. 114; COS, cf. COGAN, 2000, p. 304; POZZER, 2013, p. 27, n. 37, p. 28, n. 39. 
Enfim, para considerarmos uma audiência por princípios culturais. A destacada exposição dos relevos e a "Carta ao deus" demonstram adequadamente que Senaquerib considerou a sua campanha contra Judah como a sua grande vitória (LIVERANI, 2017, p. 128-29); diga-se, a destruição de Lakish e a tributação imposta a Jerusalém - a capital do antigo reino vassalo sobreviveu ao assédio "como um pássaro na gaiola". Os relevos como agentes históricos têm em vista pessoas em condições sociais de atender a uma convocação de exposição e leitura públicas reais, tomadas pelo espírito da missão imperial. Com rigor, Ariel Bagg (2016, p. 61, 65) resume a apenas duas categorias: o público presente, "esse círculo era restrito aos escribas e eruditos", e o público implícito, esse "era principalmente os futuros reis e deuses". ${ }^{27} \mathrm{Com}$ uma mensuração baseada nesse tipo de acesso restritivo, Pozzer (2013, p. 30) conclui que "esses relevos monumentais foram expostos nas paredes internas dos palácios e, portanto, sua circulação era restrita aos convidados do rei, às delegações diplomáticas estrangeiras e à própria corte assíria”. Tendo essas categorias, Battini (2019, p. 349-50) auxilia-nos na compreensão do valor da função política que era atribuída aos relevos e às locações internas do palácio: a assim chamada Sala do Trono era de fácil acesso a visitantes do palácio, enquanto a Sala XXXVI, apesar de comportar um pequeno número de pessoas, localizava-se na parte interna de uma área mais cenográfica e podia ser vista por grande público que acessasse o pátio XIX.

\section{Conclusão}

Retomemos os contextos históricos numa crítica da apreensão da informação e de conhecimentos transmitidos pelos relevos - as obras de arte. O império neoassírio, o rei Senaquerib, o Levante e Lakish - sempre lá desde o Neolítico! - forças de defesa, invasores, imagens de destruição ou baixos-relevos e inscrições, o carregamento do butim, o extermínio da população, as encenações das memórias artísticas da violência. No quadro político transregional emerge o perspectivismo da aparência na qual as culturas estão no plano de fundo das imagens. Então, a experiência estética transmite o componente de sentido necessário para que as imagens sejam transformadas em agentes históricos. Foi o que este ensaio historiográfico buscou nos sofisticados relevos assírios: o componente de sentido ou intervenção humana e a agência ou encenação da memória histórica.

27 Nesse sentido, uma proposição política de projeto real por meio de inscrições ou anais pode ser aplicada aos monumentos reais: "Um procedimento de escrituração, que talvez dificulte uma historicização provável, consiste em flexibilizar a interpretação do fenômeno presenciado e as fontes, copiadas segundo a finalidade do registro, como estimular a sua própria aceitação (aceitação do autor ou do sujeito biografado) por parte dos deuses e do povo, armazenar informações, proceder à memorização, mas ainda permitir a retificação em parte do registro" (SANTOS, 2013, p. 14). 
A materialidade artística da violência promove em perspectiva o domínio mundial da Assíria; se internamente a exposição das obras de arte e publicação das inscrições podem ser vistas como propaganda ideológica, externamente desperta resistências aos modos políticos assírios. Isso levou-nos à análise dos contextos, num período em que a Assíria consolida o seu domínio mundial. Com relação ao assédio e destruição da cidade de Lakish, as pesquisas das ruínas do sítio arqueológico revelam as intensas atividades da cidade-Estado no século VIII, como trazidas ao debate comparativamente.

Em adição, os relevos da Sala XXXVI do palácio fazem parte de um sistema de demonstrações de poder - as guerras como presentismos exemplares. Por isso a atividade simbólica ganha um componente de sentido por meio da audiência, implica na sua significação e nos relevos, esses agentes históricos com o público, num ambiente de encenações políticas reais. Eis a aporia dos relevos da destruição de Lakish dirigida à mensagem política imagética transmitida, seja como retórica para o público interno, seja como ameaça para uma não-audiência por motivos políticos.

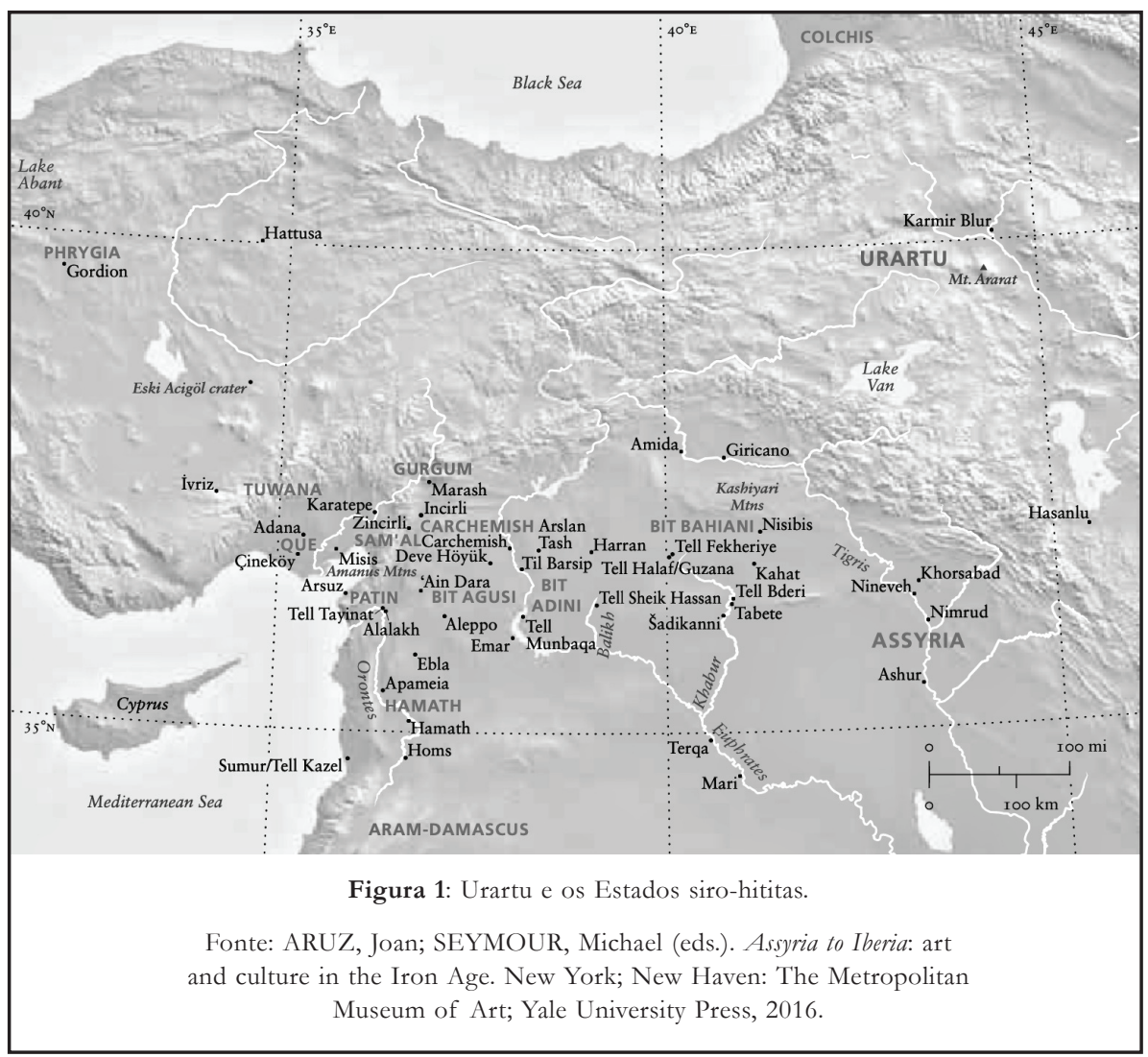




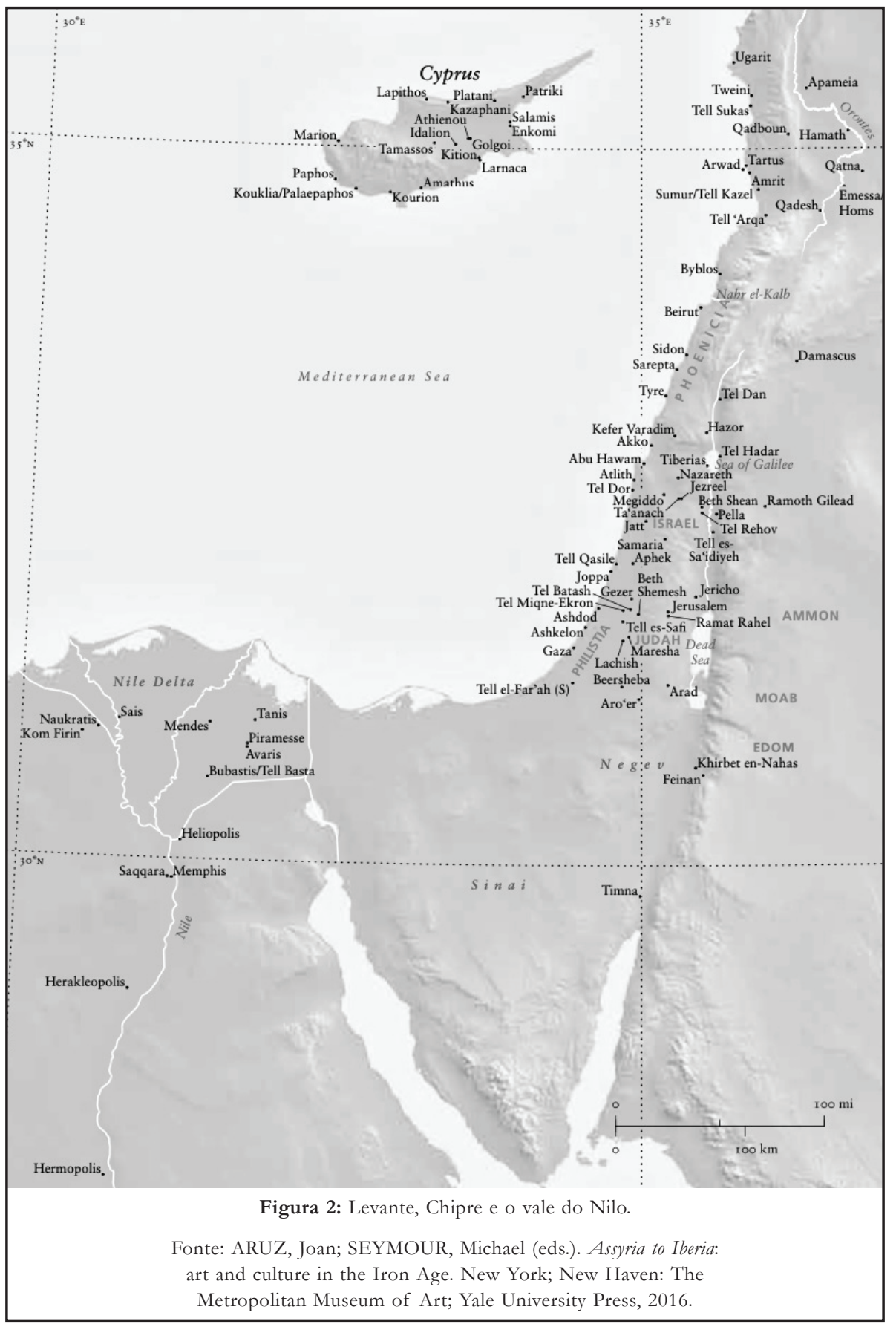




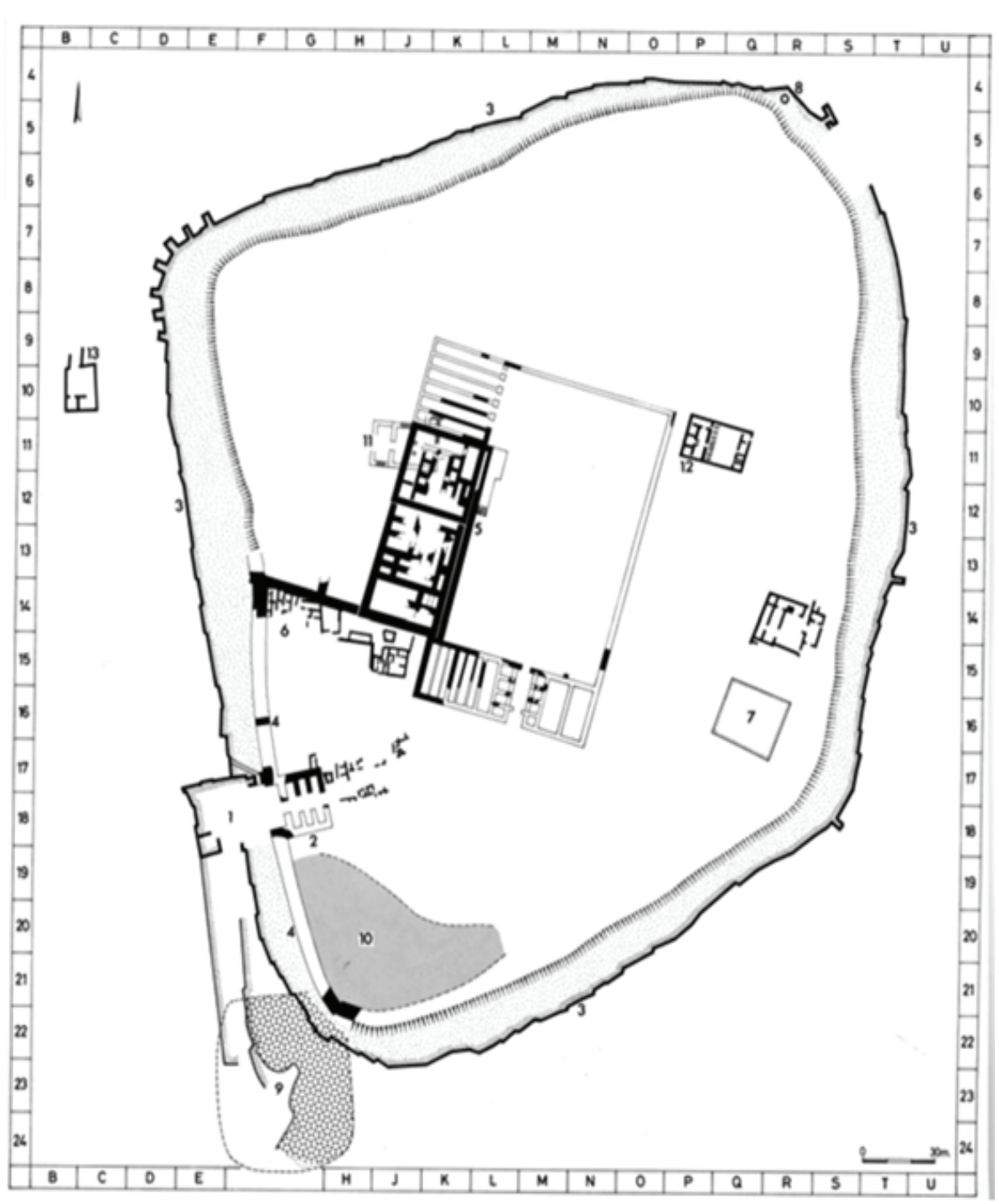

Figure 3: Tel Lakish: (1) portão externo da cidade; (2) portão interno; (3) revestimento externo; (4) muro principal da cidade; (5) complexo da fortaleza do palácio; (6) área $\mathrm{S}$ - a trincheira de escavação principal; (7) o grande eixo; (8) o poço; (9) rampa de assédio assírio; (10) a rampa interna; (11) monte do templo; (12) santuário ao ar livre; (13) fosso do templo (USSISHKIN, 2014, p. 78). 


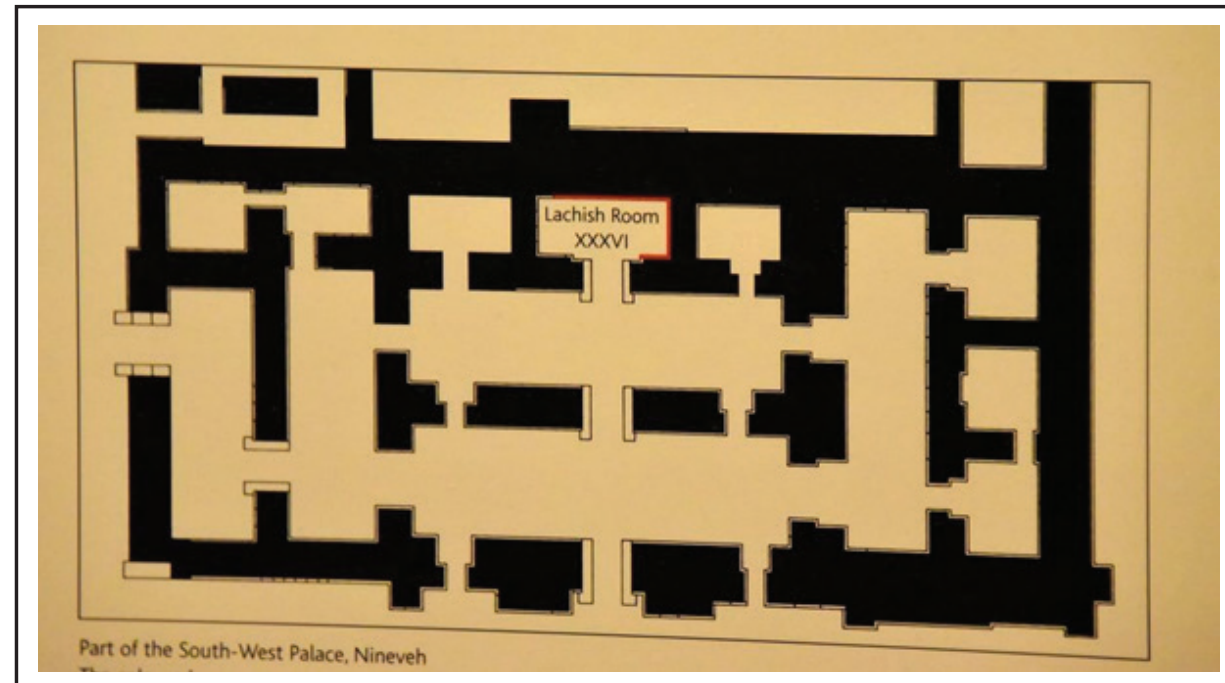

Figura 4: Plano do "Palácio Sudoeste" de Senaquerib em Nínive.

A sala XXXVI foi marcada com linhas vermelhas para mostrar o alinhamento original e a posição dos relevos. Trustees The British Museum.

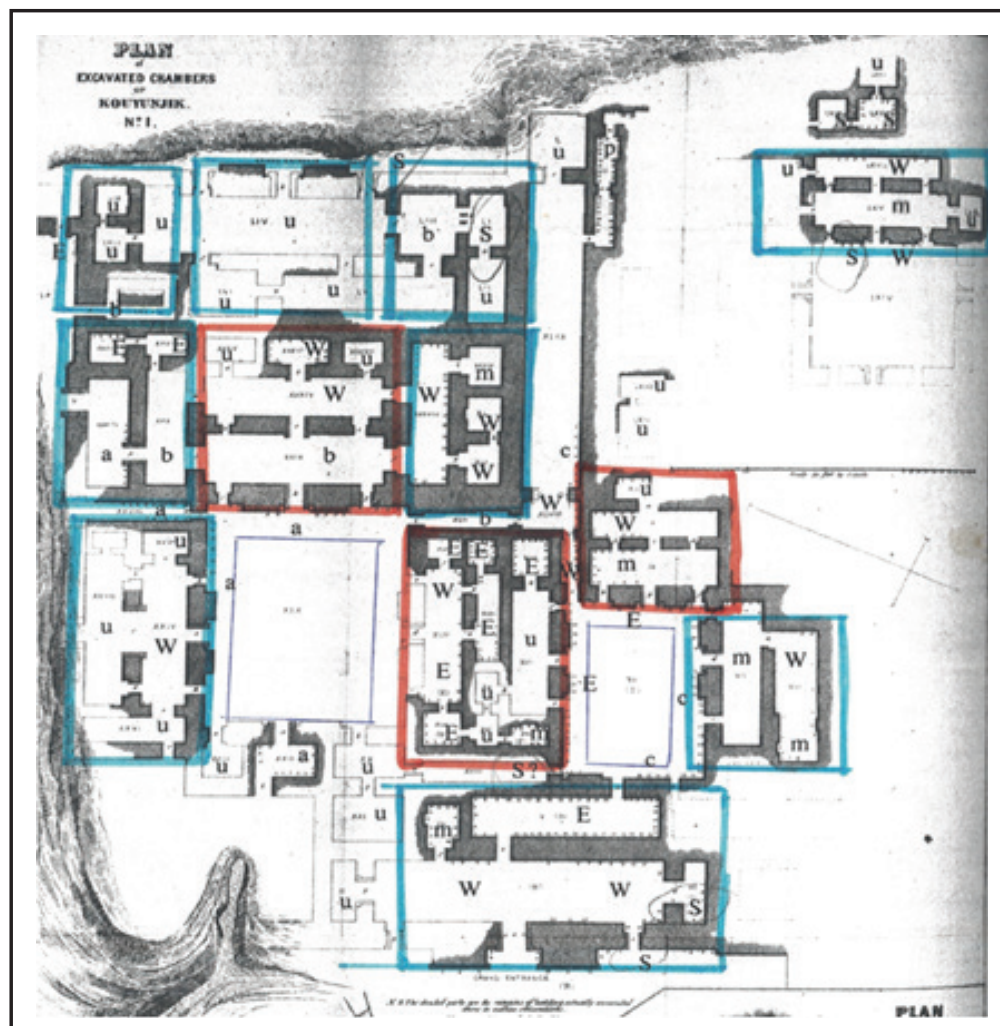

Figura 5: Quatorze unidades geométricas dentro do palácio de Senaquerib (restituição). BATTINI, 2019, p. 369. 


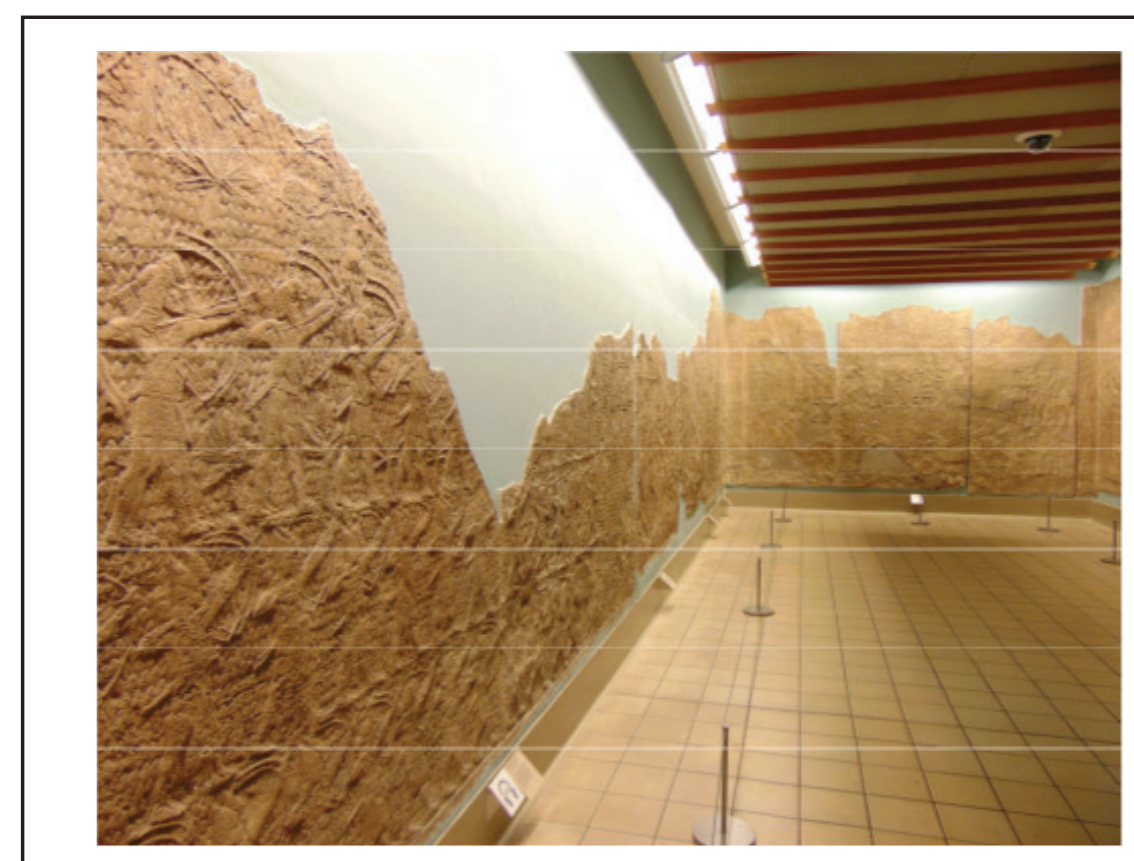

Figura 6: Sala 10b no Museu Britânico. Os relevos das paredes do assédio de Lakish podem ser vistoszaqui com suas descrições correspondentes. Trustees The British Museum.
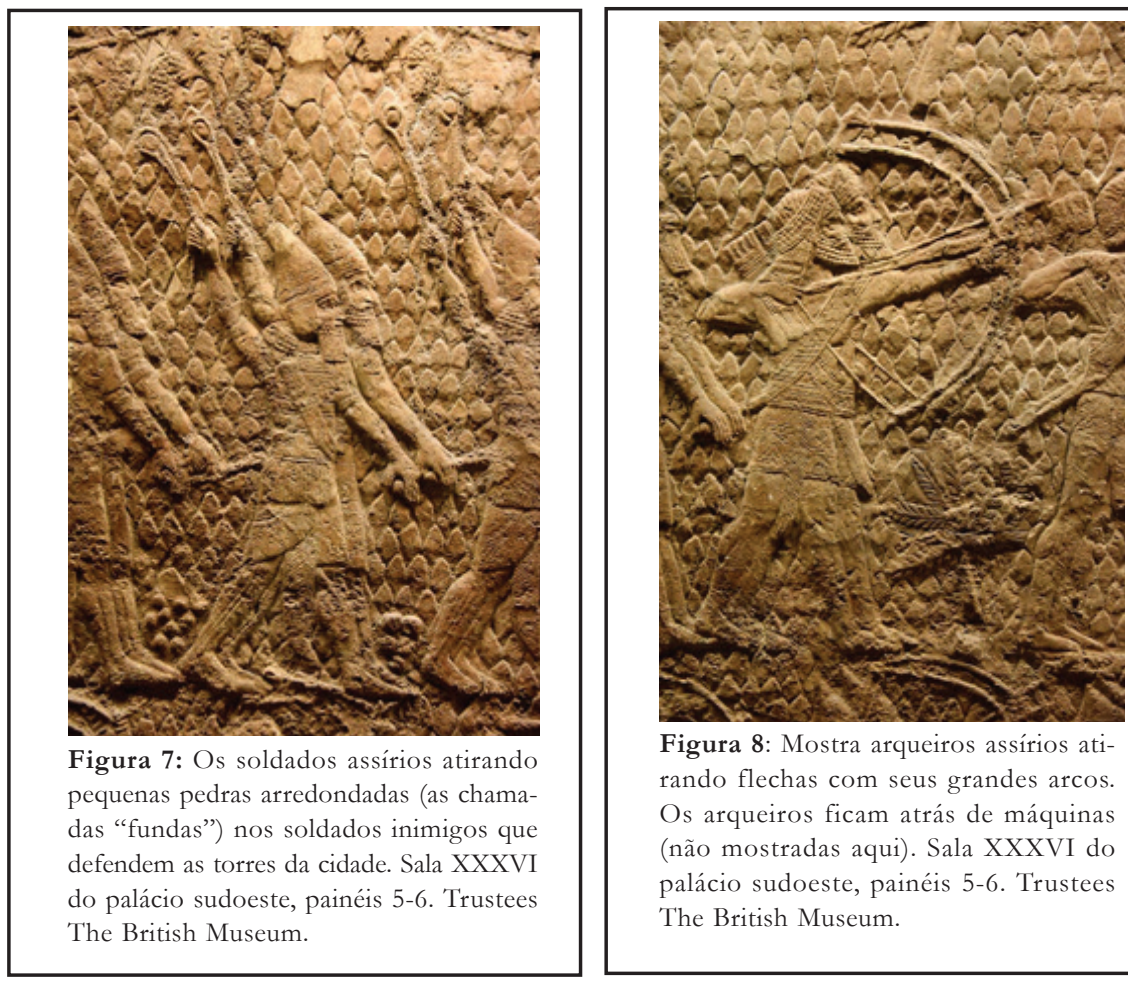

Figura 8: Mostra arqueiros assírios atirando flechas com seus grandes arcos. Os arqueiros ficam atrás de máquinas (não mostradas aqui). Sala XXXVI do palácio sudoeste, painéis 5-6. Trustees The British Museum. 


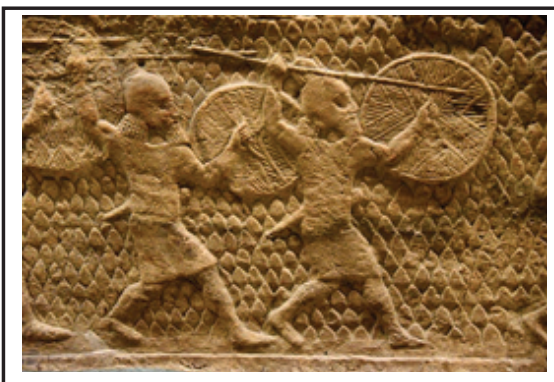

Figura 9: $\mathrm{O}$ início do ataque a Lakish em 701 AC. Este é um detalhe de um grande painel de parede de pedra que mostra soldados assírios em ação, segurando suas longas lanças e escudos arredondados. Sala XXXVI do palácio sudoeste, painéis 5-6. Trustees The British Museum.

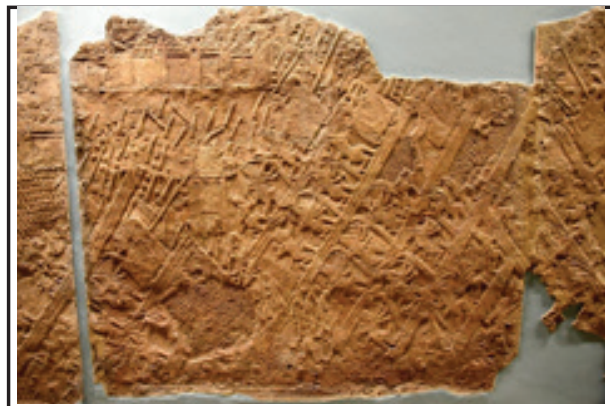

Figura 10: Os assírios tiveram que construir várias rampas para transportar seu equipamento militar até o alto da colina, a fim de alcançar as muralhas e o portão da cidade. O portão da cidade estava situado no lado sul da colina, que era muito mais íngreme do que sua contraparte norte. Máquinas do assédio e soldados estão subindo e atacando a cidade. Os defensores (soldados nas torres da cidade) estão tentando desesperadamente atirar flechas, atirar pedras e pedras e derramar água sobre os assírios. Após algumas semanas de assédio, a cidade foi saqueada e os assírios conquistaram a cidade. Sala XXXVI do palácio sudoeste, painel 7. Trustees The British Museum (BM 124906).

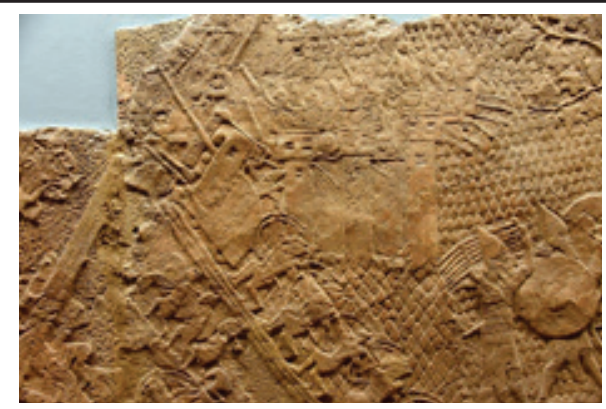

Figura 11: Aqui, o exército assírio está esmagando o inimigo e atingiu a muralha da cidade. Os soldados de Lakish ainda estão em suas torres de proteção. Sala XXXVI do palácio sudoeste, painel 7. Trustees The British Museum.

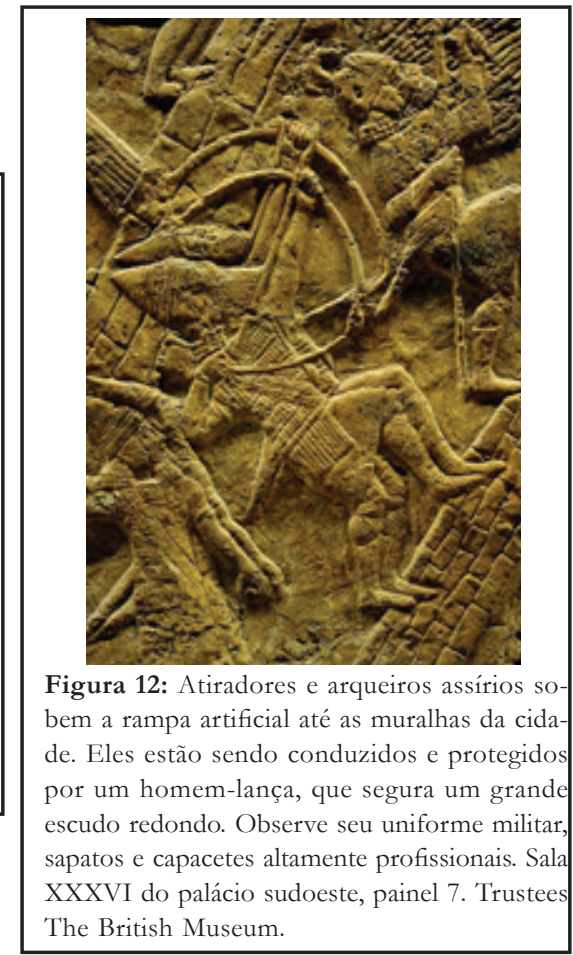




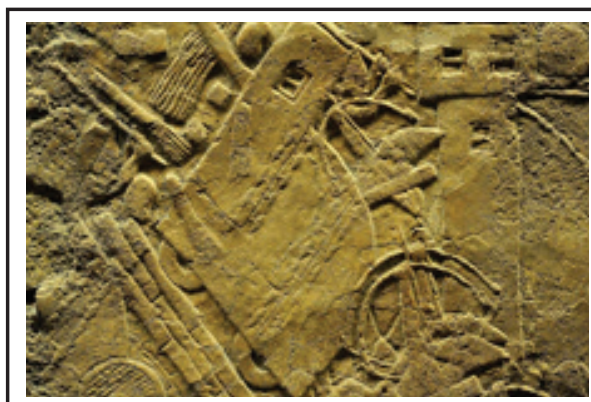

Figura 13: Uma máquina usada no assédio sobe a rampa. Este é um veículo com rodas com uma plataforma para arqueiros - um aríete pode ser acoplado na frente para quebrar portões ou paredes. O motor está sendo atacado por pedras, rochas e tochas de fogo. Uma das torres de Lakish aparece no lado direito. Sala XXXVI do palácio sudoeste, painel 7. Trustees The British Museum.

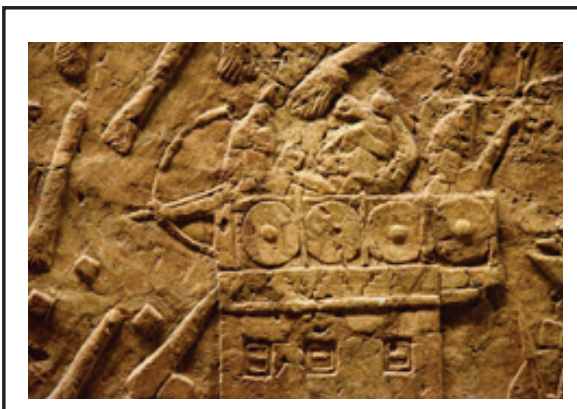

Figura 15: Os defensores estão posicionados em uma das torres da muralha da cidade, tentando repelir os assírios. Um soldado está jogando uma flecha, enquanto seus companheiros estão jogando pedras e pedras. O ambiente ao redor é bombardeado com tochas de fogo e pedras. Sala XXXVI do palácio sudoeste, painel 7. Trustees The British Museum.

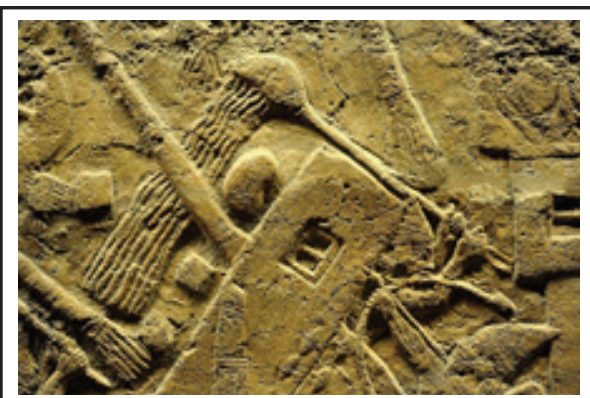

Figura 14: Esta é uma cena dinâmica. $O$ aríete da máquina está sendo atacado por tochas de fogo, que foram lançadas pelos soldados de Lakish. Um dos soldados assírios, dentro do motor, está pronto e parece antecipar o ataque. Ele está jogando água no motor para evitar que pegue fogo. Apesar de todos os danos, parece que o motor está imune a este ataque. Sala XXXVI do palácio sudoeste, painel 7. Trustees The British Museum.

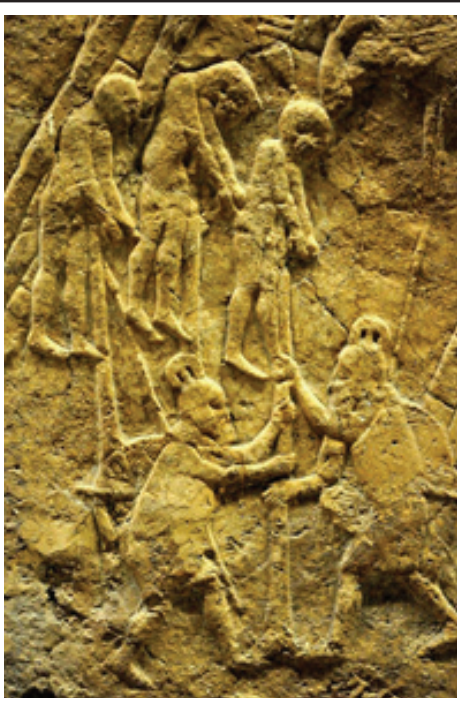

Figura 16: No início da batalha, alguns dos soldados de Lakish foram capturados pelo exército assírio. Este detalhe do painel de pedra descreve o processo de empalamento: Três prisioneiros de guerra estão sendo empalados por soldados assírios na frente da cidade, uma técnica usada para suprimir rebeliões e aterrorizar os habitantes. Observe que as vítimas parecem algemadas e nuas. Sala XXXVI do palácio sudoeste, painel 7. Trustees The British Museum. 


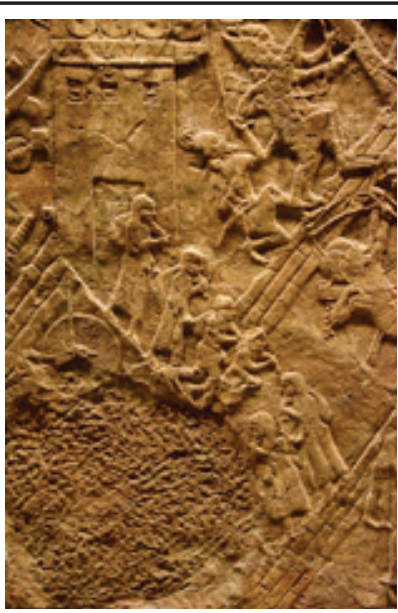

Figura 17: As forças de defesa de Lakish começaram a entrar em colapso aqui. O portão da cidade foi aberto, e os habitantes da cidade estão fugindo, segurando seus pertences pessoais ou o que quer que possam trazer com eles. Este detalhe mostra mulheres e dois homens. Parece que eles estão descendo a colina e chegaram à rampa artificial assíria. Parece que o exército assírio os deixa ir sem matá-los no local. Os assírios avançam enquanto os defensores de Lakish resistem desesperadamente à invasão. Sala XXXVI do palácio sudoeste, painel 7. Trustees The British Museum.

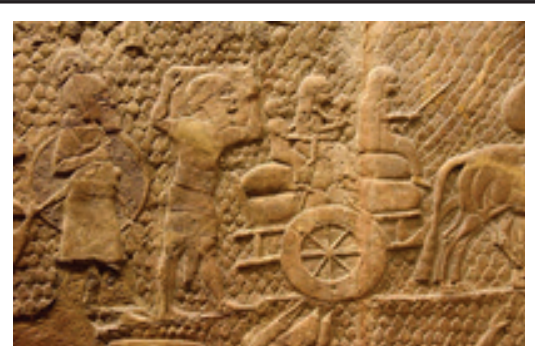

Figura 18: Um soldado assírio guia uma família deportada de Lakish. Um homem segura uma grande caixa nos ombros. Uma jovem guia uma carroça de duas rodas puxada por um touro, enquanto uma mulher segura um menino e uma menina. Sala XXXVI do palácio sudoeste, painéis 8-9. Trustees The British Museum.

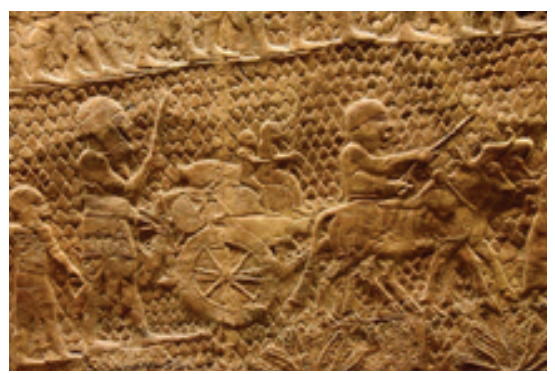

Figura 19: Outra família judaíta exilada; observe seus pertences pessoais e as crianças pequenas. Sala XXXVI do palácio sudoeste, painéis 8-9. Trustees The British Museum.

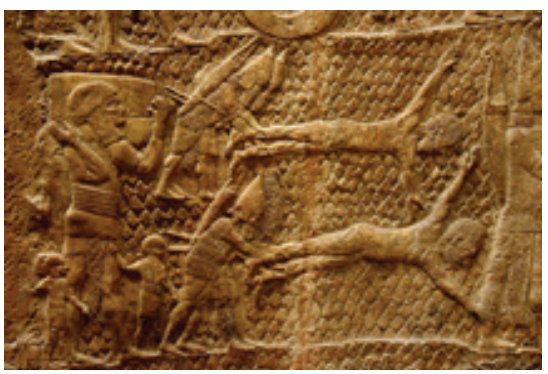

Figura 20: Lakish entrou em colapso e suas forças de defesa foram esmagadas. À esquerda, homens com suas esposas, filhos e alguns pertences estão sendo deportados para reassentamentos assírios. À direita, os membros da força de defesa local são executados. Este detalhe do painel mostra que soldados assírios estão esfolando dois prisioneiros. Sala XXXVI do palácio sudoeste, painéis 9-10. Trustees The British Museum. 

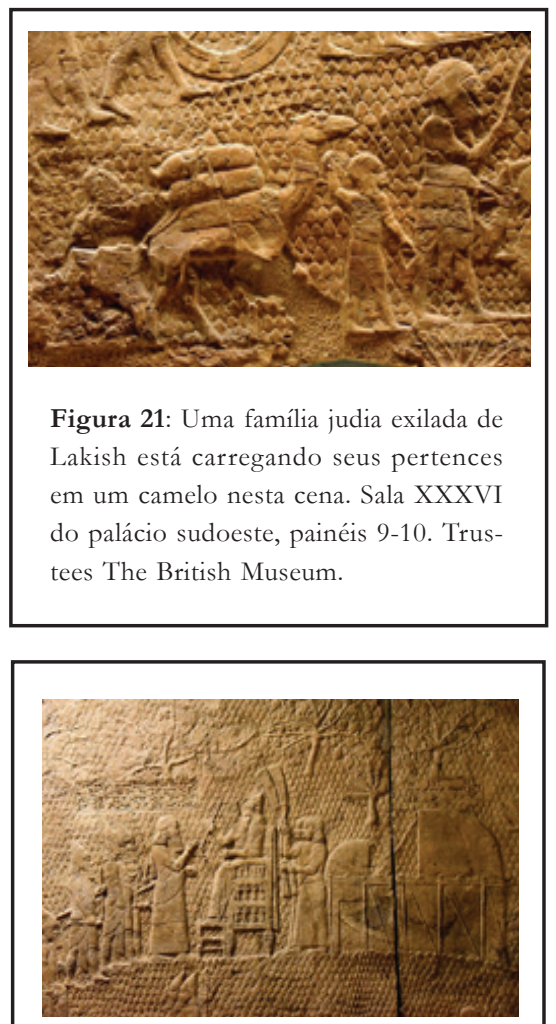

Figura 23: No final da batalha e captura de Lakish, Senaquerib se senta em um trono magnífico. Ele cumprimenta seu comandante-chefe, que está diante dele. $\mathrm{O}$ exército do rei desfila saques e prisioneiros de guerra (não mostrados aqui) na frente dele. Os guarda-costas do rei estão posicionados ao seu redor. Dois atendentes estão atrás de Senaquerib, agitando batedeiras para que nada, nem mesmo pequenas criaturas zumbindo no ar, perturbe a tranquilidade do rei. Há uma tenda real atrás do rei. $\mathrm{Na}$ parte superior do painel, podemos reconhecer figos e vinhas. A inscrição cuneiforme à esquerda diz: "Senaquerib, rei do mundo, rei da Assíria sentou-se em um trono, e o butim de Lakish passou diante dele". O rosto do rei foi posteriormente desfigurado, talvez após a queda de Nínive no ano 612. Sala XXXVI do palácio sudoeste, painéis 11-13. Trustees The British Museum.

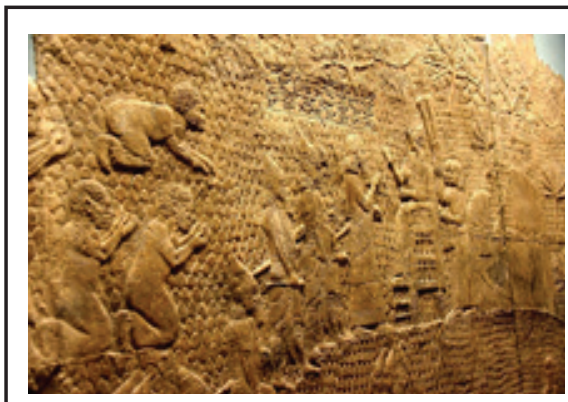

Figura 22: O rei assírio Senaquerib está sentado em sua luxuosa cadeira em um monte baixo. Há uma tenda atrás dele; seu comandante-chefe está próximo a ele e o cumprimenta após conquistar a cidade de Lakish. Soldados assírios, usando uniforme militar, carregam suas armas. Os prisioneiros de Lakish estão sendo revistos e apresentados ao rei. Um prostrou-se e outros dois se ajoelharam; eles parecem pedir misericórdia, provavelmente antes da decapitação. Sala XXXVI do palácio sudoeste, painéis 11-13. Trustees The British Museum.

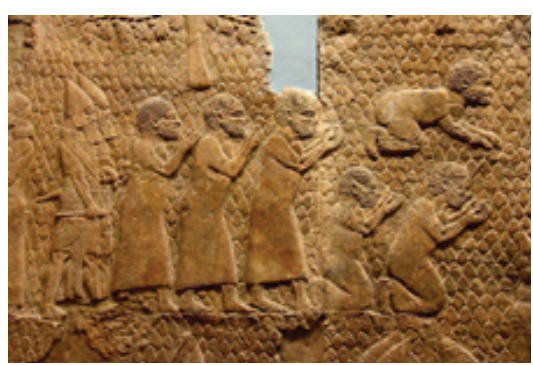

Figura 24: Soldados assírios desfilando os prisioneiros de guerra diante de Senaquerib (à direita e não mostrado aqui). Muito provavelmente a cena apresenta os chefes da rebelião. Todos estão descalços e sem roupa na cabeça, o que é um sinal de humilhação. Todos eles parecem pedir misericórdia diante do rei, mesmo os que ficaram de pé; a execução deles seria indubitável. Sala XXXVI do palácio sudoeste, painéis 11-13. Trustees The British Museum. 


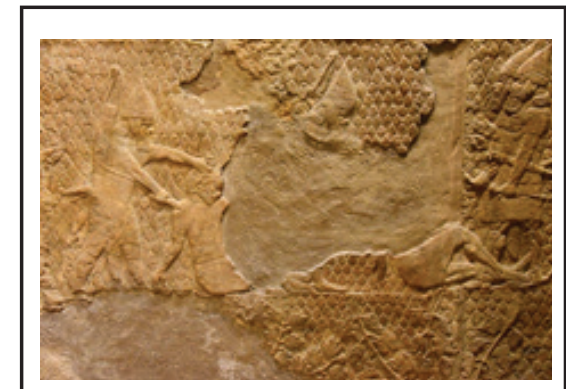

Figura 25: Alguns dos prisioneiros são decapitados aqui. O da esquerda está prestes a ser decapitado por um soldado assírio. Outro prisioneiro à direita (a maior parte de seu corpo está perdido) já foi decapitado; sua postura supina e flácida sugere isso. Dois soldados assírios no lado direito observam o processo de decapitação. Sala XXXVI do palácio sudoeste, painéis 11-13. Trustees The British Museum.

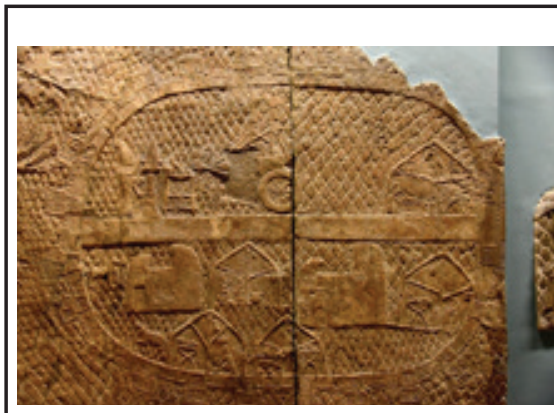

Figura 26: Este painel mostra o acampamento de guarnição assíria de onde o assédio foi conduzido. É fortificado com uma estrada que passa no meio. Vemos pessoas trabalhando em tendas, e dois sacerdotes, com incensários, estão realizando uma cerimônia em frente às carruagens nas quais estão montados os estandartes da divindade. Sala XXXVI do palácio sudoeste, painéis 14-16. Trustees The British Museum.

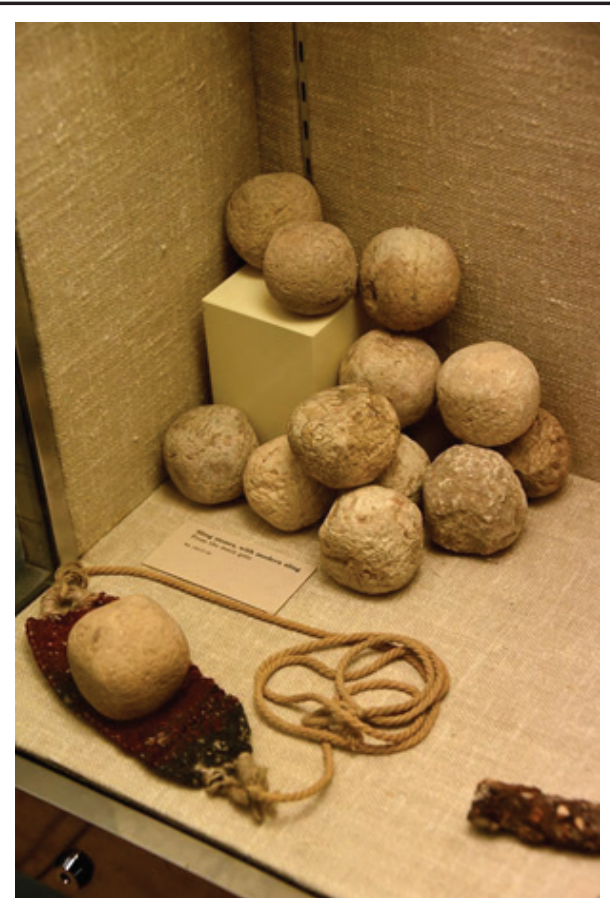

Figura 27: Essas pedras foram escavadas no Nível III do portão da cidade de Lakish. Elas foram lançadas pelos soldados assírios nas torres da cidade. Doado por Sir Henry Solomon Wellcome em 1956. Trustees The British Museum. 


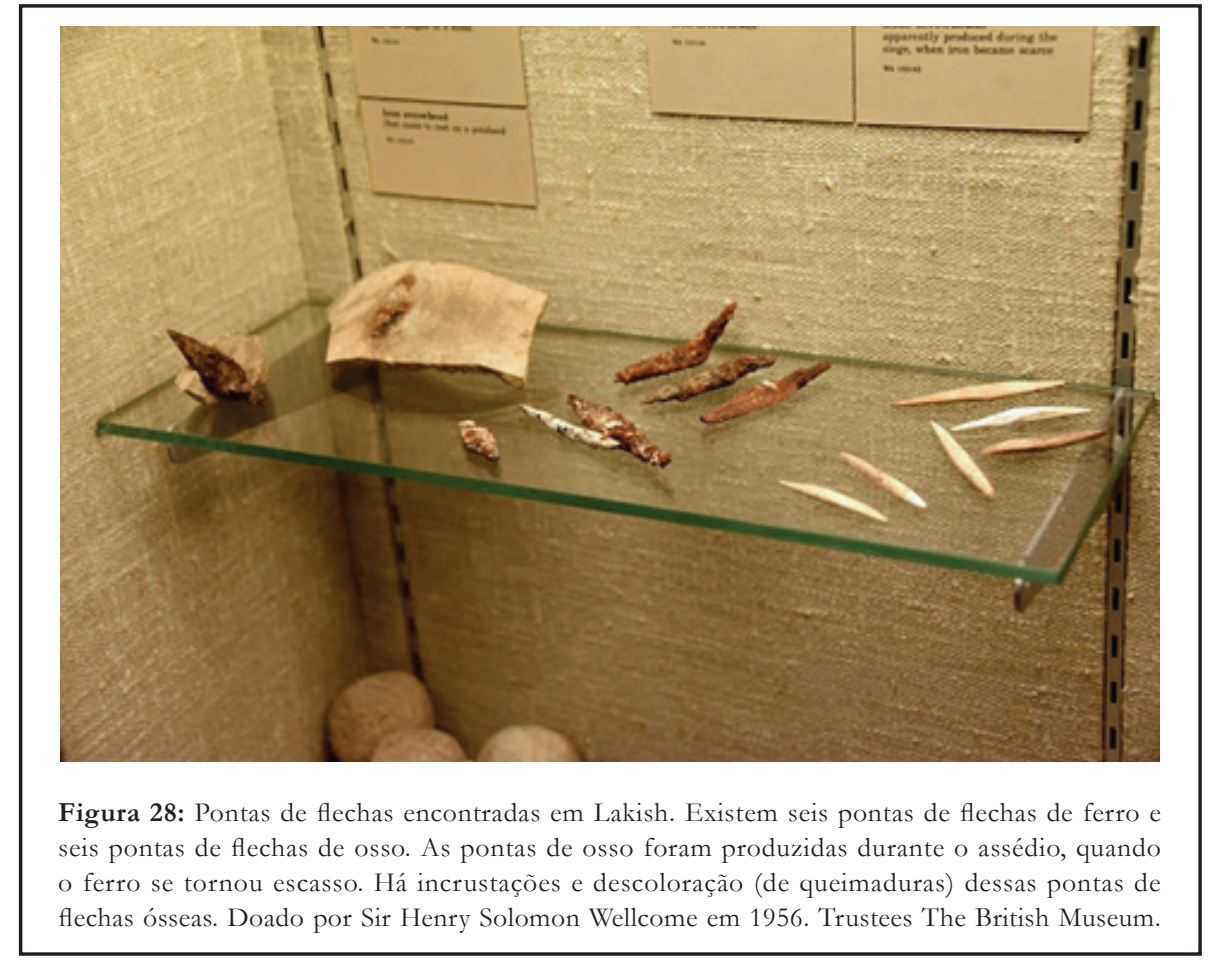

\section{Abreviações bibliográficas}

AANEA - Archaeopress Ancient Near Eastern Archaeology

ÄAT - Ägypten und Altes Testament (Studien zu Geschichte, Kultur und Religion Ägyptens und des Alten Testaments)

ABS - Archaeology and Biblical Studies

BHS - Biblia Hebraica Stuttgartensia

COS - The Context of Scripture

FSAVK - Freiburger Studien zur Archäologie und Visuellen Kultur

SAAS - State Archives of Assyria Studies

SBL - Society of Biblical literature archaeology and Biblical Studies

VTSup - Supplements to Vetus Testamentum

\section{Referências bibliográficas}

ABRAHAMI, Philippe. La guerre. In: BORDREUIL, Pierre; BRIQUEL-CHATONNET, Françoise; MICHEL, Cécile (dir.). Les débuts de l'Histoire: civilisations et cultures du Proche-Orient ancien. Nouvelle édition revue et augmentée. Paris: Éditions Khéops, 2014, p. 220-226. 
BACHELOT, Luc. La function politique des reliefs Néo-Assyriens. In: CHARPIN, Dominique; JOANNÈS, Francis (dir.). Marchands, diplomates et empereurs. Études sur la civilization mésopotamienne offertes à Paul Garelli. Paris: Éditions Recherche sur les Civilisations, 1991, p. 109-128.

BAGG, Ariel. Where is the public? A new look at the brutality scenes in Neo-Assyrian royal inscriptions and art. In: BATTINI, Laura (ed.). Making pictures of war: Realia et imaginaria in the iconology of the ancient Near East. (ANEA 1). Oxford: Archaeopress Publishing, 2016, p. 57-82.

BATTINI, Laura. Consented violence in the collective memory: the Lachish case from epigraphic and iconographic data. Semitica, Paris, v. 61, p. 337-371, 2019.

COGAN, Mordechai. Sennacherib: the "Azekah" inscription (2.119D). In: HALLO, William W. (ed.). The Context of Scripture. Vol. 2: Monumental inscriptions from the biblical world. Leiden: Brill, 2000, p. 304-305.

COLLINS, Paul. Gods, heroes, rituals, and violence: warfare in Neo-Assyrian art. In: BROWN, Brian A.; FELDMAN, Marian H. (eds.). Critical approaches to ancient Near Eastern art. Berlin: Walter de Gruyter, 2014, p. 619-644.

DEVER, William G. Archaeology and the question of sources in Kings. In: LEMAIRE, André; HALPERN, Baruch (eds.). The Books of Kings: sources, composition, historiography, and reception. (VTSup 129). Atlanta, GA: SBL Press, 2010, p. 517-538. [Leiden: Koninklijke Brill, 2010].

ELLIGER, Karl; RUDOLPH, Wilhelm (hrsg.). Biblia Hebraica Stuttgartensia. 5. aufl. Stuttgart: Deutsche Bibelgesellschaft, 1997.

FRANKLIN, Norma. The kushite connection: the destruction of Lachish and the salvation of Jerusalem. In: SHAI, Itzhaq; CHADWICK, Jeffrey R.; HITCHCOCK, Louise; DAGAN, Amit; McKINNY, Chris; UZIEL, Joe (eds.). Tell it in Gath. Studies in the history and archaeology of Israel. Essays in honor of Aren M. Maeir on the occasion of this sixtieth birthday. (ÄAT 90). Münster: Zaphon, 2018, p.680-695.

HARDIN, James W. Judah during the Iron Age II Period. In: STEINER, Margreet L.; KILLEBREW, Ann E. (eds.). The Oxford handbook of the archaeology of the Levant. c. 8000-332 BCE. Oxford: Oxford University Press, 2014, p. 743-756.

LIVERANI, Mario. Le lettere di el-Amarna. Vol. 1: Le letterre dei "Piccoli Re". Brescia: Paideia Editrice, 1998.

LIVERANI, Mario. Le lettere di el-Amarna. Vol. 2: Le letterre dei “Grandi Re”. Brescia: Paideia Editrice, 1999.

LIVERANI, Mario. Para além da Bíblia: história antiga de Israel. Trad. Orlando Soares Moreira. São Paulo: Loyola, 2008.

LIVERANI, Mario. Assyria: the imperial mission. Trad. Andrea Trameri and Jonathan Valk. Winona Lake, IN: Eisenbrauns, 2017.

MIEROOP, Marc van de. Historia del Próximo Oriente antiguo: ca. 3000-323 A.E.C. Trad. Sara Arroyo y Andrés Piquer. Madrid: Trotta, 2020.

NADALI, Davide. Bas-reliefs as a source for Neo-Assyrian history. In: LANFRANCHI, Giovanni Battista; MATTILA, Raija; ROLLINGER, Robert (eds.). Writing Neo-Assyrian 
history: sources, problems, and approaches. (SAAS 29). Helsinki: Neo-Assyrian Text Corpus Project, 2019, p. 329-339.

NADALI, Davide. Representations of violence in ancient Mesopotamia and Syria. In: FAGAN, Garrett G.; FIBIGER, Linda; HUDSON, Mark; TRUNDLE, Matthew (eds.). The Cambridge world history of violence. Vol. I: The Prehistoric and ancient worlds. Cambridge: Cambridge University Press, 2020, p. 629-653.

NADALI, Davide; PORTUESE, Ludovico. Archaeology of images: contexto and interconicity in neo-assyrian art. In: BRACKER, Jacobus (ed.). Homo pictor: image studies and archaeology in dialogue. (FSAVK 2). Heidelberg: Propylaeum, Universitätsbibliothek Heidelberg 2020, p. 127-157.

POZZER, Katia Maria Paim. Relações de poder no império assírio: arqueologia e iconografia da conquista de Lakiš. Maracanan, Rio de Janeiro, v. 9, n. 9, p. 10-30, 2013.

SANTOS, João Batista Ribeiro. Pertinências entre os anais egípcios e a biografia antiga: ensaio historiográfico sobre escrita e ideologia nas inscrições cuneiformes e hieroglíficas de eventos oficiais e memoriais do Egito antigo. Em Tempo de Histórias, Brasília, n. 23, p. 7-21, 2013.

SANTOS, João Batista Ribeiro. O monumento do rei Meša‘ de Mū’aba: o liame dos fatos envolvendo moabitas e israelitas do norte na Idade do Ferro II. Phoînix, Rio de Janeiro, v. 25, n. 2, p. 11-25, 2019.

SCHMID, Konrad. História da literatura do Antigo Testamento: uma introdução. Trad. Uwe Wegner. São Paulo: Loyola, 2013.

SCHNEIDER, Tammi J. Mesopotamia (assyrians and babylonians) and the Levant. In: STEINER, Margreet L.; KILLEBREW, Ann E. (eds.). The Oxford handbook of the archaeology of the Levant: c. 8000-332 BCE. Oxford: Oxford University Press, 2014, p. 98-106.

SIDDALL, Luis R. Text and context: the question of audience for Sennacherib's "public" inscriptions. In: KEIMER, Kyle H.; DAVIS, Gillan (eds.). Registers and modes of communication in the ancient Near East. getting the message across. London: Routledge, 2018, p. 59-68.

STREIT, Katharina. The stranger on the mound: tracing cultural identity at Tel Lachish during the Late Bronze Age. In: MYNÁŘOVÁ, Jana; KILANI, Marwan; ALIVERNINI, Sergio (eds.). A stranger in the house: the crossroads III. Proceedings of an international conference on foreigners in ancient egyptian and Near Eastern societies of the Bronze Age held in Prague, september 10-13, 2018. Prague: Charles University, Faculty of Arts, 2019, p. 355-370.

THOMASON, Allison Karmel. From Sennacherib's bronzes to Taharqa's feet: conceptions of the material world at Nineveh source. Iraq, London, v. 66, p. 151-162, 2004. [On-line: Cambridge, 2014].

USSISHKIN, David. Sennacherib's campaign to Judah: the archaeological perspective with an emphasis on Lachish and Jerusalem. In: KALIMI, Isaac; RICHARDSON, Seth (eds.). Sennacherib at the gates of Jerusalem: story, history and historiography. Leiden: Brill, 2014, p. 75-103.

YOUNGER, Lawson K. A political history of the arameans: from their origins to the end of their polities. (ABS 13). Atlanta, GA: SBL Press, 2016. 


\section{Reconhecimento}

Agradeço a Luísa Batista pelo auxílio nas buscas e catalogação de fontes para esta pesquisa; seu auxílio às minhas pesquisas vem desde 2017, quando tinha 14 anos de idade.

A versão inicial desta pesquisa, contendo cerca de 2.400 palavras (c. $1 / 4$ da pesquisa atual), foi apresentada como monografia final no curso "Cultura Material e Visual: os relevos palacianos assírios em contextos e como fontes históricas" (FLH5588 - FFLCH/USP), oferecido pela Universidade de São Paulo, ministrado pelo professor Leandro Penna Ranieri e supervisionado pelo professor Marcelo Rede entre os dias 2 e 30 de setembro de 2020. Agradeço, portanto, ao Leandro pelo curso e pelas considerações àquela monografia. 